\title{
CONCEPTO DE DERECHO A LA VIDA*
}

\author{
Rodolfo Figueroa García-Huidobro**
}

\begin{abstract}
RESUMEN
Es posible identificar en la literatura nacional y extranjera cinco formas de entender el derecho a la vida: como el derecho a vivir o a permanecer vivo; como el derecho a vivir bien o vivir con dignidad; como el derecho a recibir todo lo mínimamente necesario para no morir en lo inmediato; como el derecho a que no nos maten y, finalmente, como el derecho a que no nos maten arbitrariamente. En este trabajo, se presentan esas cinco concepciones, se analizan críticamente y se proporcionan razones para defender la última concepción, aquella según la cual el derecho a la vida consiste en el derecho a que no nos maten arbitrariamente. Además de lo anterior, en este trabajo se aborda y se discute la tesis de la indisponibilidad de la vida.
\end{abstract}

\begin{abstract}
Both in national and foreign literature it is possible to find five conceptions regarding the right to life: as the right to live or remain alive; as the right to live well or with dignity; as the right to be given all that is necessary to stay alive; as the right no to be killed and, finally, as the right no to be killed arbitrarily. In this paper all those conceptions are explained, analyzed y reasons are given to support the last one of them, that according to which the right to life is the right not to be killed arbitrarily. Besides that, this paper addresses the discussion regarding the legitimacy for an individual to take his life.
\end{abstract}

El artículo fue recepcionado el 16 de noviembre de 2007 y aprobado para su publicación el 20 de diciembre de 2008.

** Master en Derecho y candidato a doctor, University of Wisconsin-Madison. Profesor de Derecho Constitucional, Universidad Diego Portales. Correo electrónico: rodolfo.figueroa@udp.cl.. 


\section{PALABRAS CLAVE}

Derecho a la vida, vida, matar arbitrariamente.

\section{Introducción.}

En términos generales es posible afirmar que la dogmática nacional no se ha ocupado de proporcionar y analizar una definición del derecho a la vida. En efecto, si revisamos cualquier manual de derecho constitucional constataremos que no aparece una definición de qué es o qué significa el derecho a la vida. Asimismo, las revistas de derecho nacionales prácticamente no contienen artículos dedicados a esclarecer dicho concepto. Sí hay artículos dedicados al nasciturus, que se refieren básicamente a su categoría de persona y que declaran que posee derecho a la vida, pero no se refieren principalmente al concepto de derecho a la vida. En estas circunstancias, el propósito de este trabajo es trazar algunas ideas centrales para establecer ese concepto.

\section{Cinco concepciones sobre el derecho a la vida.}

Si bien en la literatura nacional, en general, no es posible hallar un concepto o una definición explícita sobre el derecho a la vida, sí es posible encontrar en algunos autores algunas declaraciones que permiten reconstruir una noción sobre el derecho a la vida. Si a esas declaraciones que exhibe cierta literatura nacional sumamos algunos aportes de literatura extranjera, podemos identificar cinco concepciones sobre el derecho a la vida: 1) Una de ellas sostiene que el derecho a la vida consiste en el derecho a vivir, a permanecer con vida. 2) Otra sugiere que este derecho consiste en el derecho a vivir bien, o vivir con dignidad. 3) Una tercera propone entender que el derecho a la vida consiste en el derecho a recibir todo lo mínimamente necesario para no morir en lo inmediato. 4) Una cuarta concepción propone entender el derecho a la vida simplemente como el derecho a que no nos maten. Finalmente, 5) una quinta postura suscribe la idea de que este derecho consiste en que no nos maten arbitrariamente.

De estas cinco concepciones, las indicadas con los números 1), 2), 4) y 5) han tenido alguna recepción en la literatura nacional. En este trabajo se proporcionarán argumentos para defender la $5^{\mathrm{a}}$ forma de concebir el derecho a la vida, a la vez que se analizarán las demás concepciones.

\section{Matar a otro arbitrariamente.}

Como se anunció, en este trabajo se sostiene la opinión de que el derecho a la vida consiste en el derecho a que no nos maten arbitrariamente. Esta concepción parte de la base de que el objeto del derecho a la vida no es la vida como una realidad fenoménica sino una conducta de terceros, la de matar arbitrariamente a otro. En consecuencia, esta concepción del derecho a la 
vida distingue el derecho a la vida de la vida. Esta distinción no es frecuente en la literatura jurídica nacional, la que asume que el derecho a la vida tiene por objeto la vida como realidad fenoménica ${ }^{1}$, salvo un caso $^{2}$.

Existen varias razones para aceptar la distinción entre el derecho a la vida y la vida y entender que el objeto del derecho a la vida no es la vida:

3.1. Para determinar el objeto del derecho a la vida partiremos con una consideración general. Siguiendo a Alexy, el objeto de un derecho a algo ${ }^{3}$ nunca puede ser una conducta de su titular ni una cosa o entidad. Si el objeto de un derecho fuera la conducta del titular, no habría relación jurídica sino una figura solipsística. Además, se confundiría un derecho con una libertad ${ }^{4}$. Un derecho a algo implica siempre una relación jurídica con otros sujetos. Tampoco puede ser objeto de un derecho una cosa o entidad, pues el derecho se estructu-

1 Es el caso de Enrique Evans, Manuel Guzmán, Mario Verdugo y Emilio Pfeffer, José L. Cea, entre otros, como veremos más adelante.

2 En Chile, sólo Gastón Gómez formula esta distinción y agrega que no cabe referirse a la vida (p. 248) sino al enunciado derecho a la vida (p. 249). En Derechos Fundamentales y Recurso de Protección. Ediciones Universidad Diego Portales. Santiago, 2005.

Banda, por su parte, sostiene: "El derecho a la vida (...) exige (...) que nadie sea privado de ella arbitrariamente..." Banda, Alfonso. "Consideraciones sobre el transplante de órganos y derecho a la vida." En Revista de Derecho. Universidad Austral. Vol. VIII, Diciembre, 1997. p. 26.

Nogueira, si bien suscribe la tesis de que el derecho a la vida significa el derecho a estar vivo, a la existencia física y biológica y cree que el objeto del derecho es la vida, ver p. 47, sin embargo declara en un aparte de su texto: "El Estado, sus órganos y agentes tienen una prohibición de causar la muerte arbitrariamente de un ser humano...". Ver Nogueira, Humberto. El Derecho a la Vida. Ed. Librotecnia, Santiago, 2007, p. 50. Con esta declaración, aislada y probablemente no deliberada, se acerca a la posición defendida en este trabajo.

3 Usando la terminología de Alexy, los derechos fundamentales comprenden derechos a algo, libertades y competencias. Alexy, R. Teoría de los Derechos Fundamentales. Centro de Estudios Constitucionales. Madrid, 1993.

4 Tratándose de una libertad, el objeto corresponde a una conducta del titular. Allí no hay relación con terceros. Por ejemplo, la libertad de expresión. La libertad de expresión significa que el titular es libre de expresarse. Aunque no haya relación con un tercero, la existencia de esta libertad es relevante porque excluye la hipótesis de que esa conducta esté prohibida. Ahora bien, la "libertad de expresión" es distinta del "derecho a la libertad de expresión", porque en este caso, a la libertad se le agrega un derecho, es decir, se regula la conducta de terceros. Así, el titular tiene libertad (no está prohibido) para expresarse y los terceros tienen obligaciones negativas y positivas a su respecto, partiendo por la obligación de no censurarlo previamente o no silenciarlo. Alexy señala que cuando a una libertad se le agrega un derecho a algo y además una competencia (capacidad jurídica de demandar) tenemos un derecho de libertad negativo perfecto. Ver Alexy, ob. cit, p. 226. En Chile, cuando aludimos a la libertad de expresión y citamos el artículo $19 \mathrm{~N}^{\mathrm{o}} 12$, en verdad estamos aludiendo a un derecho a la libertad de expresión, que merced a los artículos 20 y el 93 de la Constitución (entre otros) constituye un derecho de libertad negativo perfecto. 
raría como una relación diádica entre el titular y la cosa. Las relaciones diádicas -al igual que el solipsismo- carecen de relevancia jurídica pues no regulan la conducta de terceros.

De acuerdo con la teoría de Alexy, los derechos a algo suponen relaciones triádicas que involucran la conducta de terceros. Dicha relación se representa como DabG: $a$ es el titular, $b$ es el destinatario, $\mathrm{G}$ es el objeto del derecho y $\mathrm{D}$ simboliza la relación entre esos 3 elementos, en el sentido de que $a$ tiene frente a $b$ un derecho a G. El objeto del derecho, G, consiste en la conducta que el destinatario $b$ debe ejecutar. Si G fuera la conducta del titular del derecho, entonces la conducta de $b$ no estaría vinculada por el derecho del titular y eso tornaría en trivial a ese derecho, pues si la conducta de $b$ no estuviera regulada por el derecho, $b$ podría hacer lo que estimara pertinente, pudiendo perjudicar el derecho de $a$. En cambio, incorporando a $b$ en la relación, $\mathrm{G}$ determina qué conductas puede ejecutar $b$, y eso es lo que le da sentido al derecho de $a^{5}$.

Aplicando esta perspectiva al derecho a la vida, advertiremos que G corresponde a la conducta de terceros, que consiste en la obligación de no matar arbitrariamente. G no alude a la conducta del titular. Por ello, G no puede consistir en vivir o vivir dignamente o permanecer vivo. De ser así, la relación jurídica sería diádica (entre $a$ y su vida) y ya hemos visto por qué los derechos a algo no pueden entenderse de esa manera. Sólo entendiendo el derecho a la vida de manera triádica, $b$ tendrá la obligación de no matar arbitrariamente a $a$ y es por ello que $a$ podrá intentar disfrutar de su vida como realidad fenoménica. Dicho de otro modo, la vida tiene valor y puede ser protegida efectivamente si es que el derecho a la vida consiste en la regulación de la conducta de terceros.

3.2 Una segunda razón para descartar que el objeto del derecho a la vida sea la vida es elemental: es evidente que alguien puede perder su vida como realidad fenoménica (o soporte biológico, como lo llaman unos autores ${ }^{6}$ ), sin que se haya vulnerado su derecho a la vida. En efecto, una persona puede morir sin que la maten arbitrariamente, por ejemplo, tratándose de una enfermedad incurable. Lo contrario supone que todas las muertes ocurren por homicidio.

3.3. A lo anterior se puede agregar el desarrollo de la jurisprudencia constitucional comparada sobre el derecho a la vida. Tribunales Constitucionales extranjeros se han ocupado del derecho a la vida especialmente resolviendo requerimientos en relación con leyes que penalizaban o despenalizaban el aborto.

$5 \quad$ Ver Alexy, ob. cit, pp. 187-188

6 Ver Verdugo, Mario; Pfeffer, Emilio; Nogueira, Humberto. Derecho Constitucional. Tomo I. Ed. Jurídica. Santiago, 2005. 
a) Una diferencia no del todo explícita entre vida y derecho a la vida es posible hallar en la sentencia 53/1985, de 11/4/1985 del Tribunal Constitucional Español. En ese fallo el tribunal declaró que la Constitución protege la vida y, por ende, se protege también la vida del nasciturus, aunque él no sea titular del derecho la vida ${ }^{7}$. La diferencia entre vida y derecho a la vida no es del todo explícita pero existe en la lógica del fallo. Si se protegiera sólo el derecho a la vida, entonces el nasciturus no tendría protección ya que el Tribunal Constitucional declaró que el nasciturus no es titular del derecho a la vida.

b) Declaraciones algo más explícitas en torno a la diferencia entre vida y derecho a la vida se encuentran en la jurisprudencia de la Corte Constitucional Colombiana. Esta jurisprudencia se ha producido resolviendo requerimientos en torno al aborto. La primera vez que la corte tuvo oportunidad de abordar este asunto fue en la sentencia C-133, de $1994^{8}$. En ese caso, la corte sostuvo:

"Es cierto, que nuestra Constitución Política reconoce expresamente el derecho inviolable a la vida a quienes son personas pertenecientes al género humano; pero de allí no se sigue que la vida humana latente en el nasciturus, carezca de protección constitucional. En efecto, si el valor esencial protegido por el ordenamiento superior es la vida humana, necesariamente debe colegirse que en donde haya vida, debe existir el consecuente amparo estatal. En otros términos la Constitución no sólo protege el producto de la concepción que se plasma en el nacimiento, el cual determina la existencia de la persona jurídica natural, en los términos de las regulaciones legales, sino el proceso mismo de la vida humana, que se inicia con la concepción, se desarrolla y perfecciona luego con el feto, y adquiere individualidad con el nacimiento. La vida que la Constitución Política protege, comienza desde el instante de la gestación, dado que la protección de la vida en la etapa de su proceso en el cuerpo materno, es condición necesaria para la vida independiente del ser humano fuera del vientre de la madre. Por otra parte, la concepción, genera un tercer ser que existencialmente es diferente de la madre, y cuyo desarrollo y perfeccionamiento para adquirir viabilidad de vida independiente, concretada con el nacimiento, no puede quedar al arbitrio de la libre decisión de la embarazada. En virtud de lo anterior, el Estado tiene la obligación de establecer, para la defensa de la vida que se inicia con la concepción, un sistema de protección legal efectivo..."

Ver los Fundamentos Jurídicos $\mathrm{N}^{\mathrm{o}}$ 5, 6, 9, 10, 11 y 12.

Este es un caso de acción pública de inconstitucionalidad, mediante la cual se demandó la inconstitucionalidad del artículo 343 del Código Penal. Se trata de la penalización del aborto. La corte rechaza la solicitud, apoyando la norma penal.

$9 \quad$ Sección VII, 4, párrafos 6-9. 
Aquí vemos que la Corte Constitucional señala que se debe proteger además del derecho inviolablealavida,lavidamisma.Estadoctrinallevóalacorteaestimarqueelabortodebíapenalizarse y por ello rechazó la petición del demandante de declarar inconstitucional la norma penal. ${ }^{10}$

Doce años después del fallo citado, la postura de la corte cambió, con el fallo C-355/06, también sobre aborto ${ }^{11}$. Una de las razones fundamentales del cambio está dada precisamente por una forma distinta de valorar la vida y el derecho a la vida. En este fallo dispuso:

"Ahora bien. Dentro del ordenamiento constitucional la vida tiene diferentes tratamientos normativos, pudiendo distinguirse el derecho a la vida consagrado en el artículo 11 constitucional, de la vida como bien jurídico protegido por la Constitución. El derecho a la vida supone la titularidad para su ejercicio y dicha titularidad, como la de todos los derechos está restringida a la persona humana, mientras que la protección de la vida se predica incluso respecto de quienes no han alcanzado esta condición." 12 (...) "En relación con esta distinción cabe recordar, que por ejemplo en la sentencia C-133 de 1994, la Corte no reconoció expresamente al nasciturus el carácter de persona humana y titular del derecho a la vida...."13 (...) “...considera esta Corporación que determinar el momento exacto a partir del cual se inicia la vida humana es un problema al cual se han dado varias respuestas, no sólo desde distintas perspectivas como la genética, la médica, la religiosa, o la moral, entre otras, sino también en virtud de los diversos criterios expuestos por cada uno de los respectivos especialistas, y cuya evaluación no le corresponde a la Corte Constitucional en esta decisión." ${ }^{14}$ (...) “...más allá de la discusión de si el nasciturus es una persona y en esa calidad titular de derechos fundamentales, es una vida humana en gestación, y como tal el Estado colombiano tiene un claro deber de protección..."15 (...) “...dentro de los límites fijados en la Constitución, determinar en cada caso específico la extensión, el tipo y la modalidad de la protección a la vida del que está por nacer corresponde al legislador,

Declaró: “...el Estado tiene la obligación de establecer, para la defensa de la vida que se inicia con la concepción, un sistema de protección legal efectivo, y dado el carácter fundamental del derecho a la vida, su instrumentación necesariamente debe incluir la adopción de normas penales..." Sección VII, 4, párrafo 9.

En este caso, al igual que en el anterior, se trató de acción pública de inconstitucionalidad, mediante la cual se demandó la inconstitucionalidad (ahora) de varios preceptos Código Penal, el cual había sido modificado con posterioridad al caso C-133. En esta oportunidad, la corte acogió la acción y declaró inconstitucionales algunas de las disposiciones del Código Penal. Sentencia C-355/06. Bogotá, D. C., diez ( 10 ) de mayo de dos mil seis (2006).

12 Sección 5 , párrafo 12.

13 Sección 5, párrafo 13. Sin embargo, como se vio más atrás, ese fallo de 1994 rechazó una solicitud de declaración de inconstitucionalidad de la prohibición del aborto.

14 Sección 5, párrafo 16.

$15 \quad$ Sección 5, párrafo 17. 
quien debe establecer las medidas apropiadas para garantizar que dicha protección sea efectiva..."16 (...) "Conforme a lo expuesto, la vida y el derecho a la vida son fenómenos diferentes. La vida humana transcurre en distintas etapas y se manifiesta de diferentes formas, las que a su vez tienen una protección jurídica distinta. El ordenamiento jurídico, si bien es verdad, que otorga protección al nasciturus, no la otorga en el mismo grado e intensidad que a la persona humana..."17

Estos párrafos permiten advertir que la corte distingue con claridad vida de derecho a la vida, y reconoce que el nasciturus no es titular del derecho a la vida porque no es persona, aunque su vida debe ser protegida por mandato de la Constitución, pues toda vida es un bien digno de protección. De todos modos, la forma de brindar protección a la vida queda entregada al legislador, quien debe proceder dentro de los límites fijados por la Carta Fundamental, y sin vulnerar los derechos de la mujer ${ }^{18}$. En esa virtud, el legislador puede permitir el aborto en ciertos casos. ${ }^{19}$

Por tanto, en este fallo encontramos una distinción explícita entre vida y derecho a la vida y además consecuencias jurídicas distintas para ambos.

3.4. Otras razones en favor de esta concepción sobre derecho a la vida aparecerán en la revisión de las demás concepciones sobre el derecho a la vida, a continuación.

\section{Discusión de las concepciones sobre el derecho a la vida.}

Se dijo el comenzar que había varias concepciones sobre el derecho a la vida. Las revisaremos ahora.

16 Sección 5 , párrafo 18.

17 Sección 5 , párrafo 20.

18 "De manera que estas consideraciones habrán de ser tenidas en cuenta por el legislador, si considera conveniente fijar políticas públicas en materia de aborto, incluidas la penal en aquellos aspectos en que la Constitución lo permita, respetando los derechos de las mujeres." Sección 5 párrafo 21.

19 En la sección 10 del fallo, la corte declara en qué casos el aborto no puede prohibirse (no puede constituir delito): cuando se trata de un embarazo que es resultado de una conducta constitutiva de acceso carnal, o acto sexual sin consentimiento, abusivo, o de inseminación artificial o transferencia de óvulo fecundado no consentidas (sección 10.1 párrafo 14 en relación con párrafo 16), o incesto (párrafo 19); o cuando la vida o la salud de la mujer están amenazadas (párrafo 23. La salud puede ser física o mental, párrafo 27); o malformaciones genéticas del feto que por su gravedad lo tornen inviable (párrafo 29). Finaliza la corte diciendo: “...la prohibición completa e incondicional del aborto en todas las circunstancias es abiertamente desproporcionada porque anula completamente derechos de la mujer embarazada garantizados por la Constitución de 1991 y por tratados internacionales de derechos humanos que hacen parte del bloque de constitucionalidad.” Sección 10.2 párrafo 38. 
4.1. La primera concepción sostiene que el derecho a la vida consiste en el derecho a vivir, a permanecer con vida o seguir viviendo. Varios autores en la literatura nacional formulan declaraciones que permiten pensar que suscriben esta concepción. Un autor señala:

"[T] odo ser humano tiene el derecho esencial de conservar su vida... (...) La vida, por ser el don primario que Dios ha dado al hombre, y por ser la fuente de sus demás atributos, está cautelada por la institucionalidad constitucional y legal...”20

Otro autor, aludiendo al derecho a la vida, sostiene:

"Hemos ya advertido que este es el derecho más importante, porque es el supuesto, la base y la finalidad de todos los demás derechos, sin excepción. Perder la vida es quedar privado de todos los derechos que sólo tenerla hace posible disfrutar."21

Un poco más adelante, este mismo autor afirma: "Esta locución (...) se refiere (...) a la persona que se halla en el vientre materno (...) Ella tiene el derecho a vivir." 22 Con esta expresión, podemos colegir que el derecho a la vida significaría el derecho a vivir, y un derecho a vivir significa un derecho a estar vivo.

Otro autor revela la misma postura:

"El derecho a la vida y a la integridad física de la persona son los derechos fundamentales por excelencia..."

Lo anterior obliga a tener presente que no se trata de unos más de los tantos derechos que encontramos en diversas declaraciones, cartas y listados, sino que constituyen una suerte de derecho germen, inicio de todos los demás y, por ello, especialmente relevante y esencial. En efecto, la vida tiene la particularidad de ser no sólo un atributo del ser humano sino que confundirse con él mismo..."23

Evans, Enrique. Derechos Constitucionales. Tomo I. Editorial Jurídica. Santiago, 2004, p. 113.

Cea,José.DerechoConstitucionalChileno. TomoII.EdicionesUniversidadCatólicadeChile.Santiago, 2004,p.89.

Cea, ob. cit, p. 94.

Vivanco, Ángela. Curso de Derecho Constitucional. Tomo II. Ediciones Universidad Católica de Chile. Santiago, 2006, pp. 242-243. Lo mismo afirma Vivanco en "El derecho a la vida y la discusión acerca del concepto de persona humana en el ámbito constitucional." En Revista Chilena de Derecho. Universidad Católica de Chile. Vol. 28, $\mathrm{N}^{\circ}$ 2, 2001. Allí sostiene muy brevemente que el derecho a la vida es el derecho a vivir, p. 476. También es el caso de Banda, aunque con una diferencia. Banda, Alfonso, ob. cit, p. 26. 
Como se puede apreciar en la cita, se habla del derecho a la vida y luego se alude a la vida. Aparentemente, también podría ser el caso de otros dos autores, que señalan:

“...se infiere que el reconocimiento al derecho a la vida aparece referido preferentemente al soporte biológico y psíquico del hombre. Es así como el derecho a la integridad física y psíquica de la persona fue aprobado por vía consecuencial: "Si una persona es mutilada o torturada, ya sea física o psicológicamente, se está atentando en contra de su vida." (Sesión $N^{\circ} 87$, pág. 4).’24

El pasaje transcrito no es del todo claro, pues al decir "referido preferentemente", eso puede significar dos cosas: referido al objeto del derecho a la vida, y en este caso sí sería similar a los casos explicados precedentemente, o podría significar referido al objeto de la obligación de terceros, que sí es la vida, y en ese caso se distanciaría de los demás autores referidos previamente.

Pues bien, esta concepción no constituye una buena aproximación dogmática al concepto del derecho a la vida por varias consideraciones:

a) En primer lugar, tener un derecho a vivir o a permanecer vivo implicaría un derecho a no morir. Esto es absurdo porque vivir es un estado fisiológico efímero. En efecto, todas las formas de vida conocidas en algún momento mueren. Esta concepción del derecho a la vida supone inmortalidad y, si bien existen creencias religiosas que incluyen la inmortalidad, debemos descartarla como parte de la dogmática constitucional.

b) En segundo lugar, y relacionado con lo anterior, muchos factores pueden conducir a que una persona no pueda seguir viviendo o permanecer con vida. Por ejemplo, puede padecer una enfermedad incurable. En ese caso, la muerte se producirá inevitablemente sin que ese resultado sea imputable a la conducta de terceros ni del Estado. Sin embargo, como el derecho a la vida se entiende -según esta concepción- como el derecho a vivir, habría que concluir que este caso de la enfermedad incurable se vulneró el derecho a la vida de esa persona, lo que no tiene sentido. En efecto, no podemos concebir los derechos de modo que ellos se puedan entender vulnerados aunque ningún ser humano -o el Estado- hubiere tenido nada que ver con ellos.

24 Verdugo, Mario; et. al, ob. cit, p. 198. Ver también la posición de Nogueira, quein señala que el derecho a la vida comprende la existencia biológica y física. Nogueira, Humberto, ob. cit, p. 50. 
c) También relacionado con el punto anterior, debemos entender los derechos de modo que sean asegurables por el Estado, al menos en algún sentido. Pues bien, no podemos entender el derecho a la vida como el derecho a vivir porque el Estado no puede asegurar vivir, debido a que los seres humanos no son inmortales.

Vale la pena aclarar que es distinto decir que el derecho a la vida significa el derecho a vivir, que sostener que el derecho a la vida implica el derecho a que no me maten arbitrariamente. La diferencia reside en que esto último no exige inmortalidad. En efecto, si una persona muere sin que la maten arbitrariamente -por ejemplo, muere porque la matan de modo justificado como sería en legítima defensa, o muere de una enfermedad inevitable- en esos casos no se vulnera su derecho a la vida.

Pasemos ahora a la segunda concepción.

4.2. Muy relacionada con la postura anterior, algunos autores - a veces los mismos que suscriben la primera concepción- apuntan que el derecho a la vida no sólo consiste en el derecho a vivir sino además a vivir bien, vivir con dignidad. Un claro ejemplo es el siguiente:

“...el derecho a la vida abarca los progresos de las ciencias biológicas y de la técnica médica para salvar la existencia de quien padece enfermedades que la ponen en peligro, o bien de proporcionarle una extensión de su vivencia con dignidad..."25.

Otro pasaje del mismo autor es ilustrativo:

"Por último, en su sentido pleno y no sólo biológico, orgánico o vegetativo, pertinente es entender también incluido en el derecho a la vida cuanto se haga para que ella transcurra en un ambiente, material y espiritualmente comprendidos, que sean coherentes con la dignidad del ser humano. El derecho a la vida no es (...) sinónimo de subsistencia en la miseria o menesterosidad, en el miedo o el riesgo. De esta condición subhumana emanan múltiples patologías, individuales y colectivas, que provocan o facilitan atentados contra la vida en las más diversas ocasiones." ${ }^{26}$

\footnotetext{
25 Cea, ob. cit, p. 94.
}

$26 \quad$ Cea, ob. cit, p. 89. 
Otro ejemplo de la misma postura es el siguiente:

"El derecho a la vida comprende el derecho a la integridad, a la salud, a la legítima defensa. No basta vivir, es necesario vivir con la plenitud de las cualidades y de los medios orgánicos de que estamos provistos por naturaleza y vivir bien para conseguir los fines humanos, rechazando aun con la fuerza la agresión injusta." 27

Esta concepción no puede compartirse por varias consideraciones harto obvias.

a) En primer lugar, vivir bien es una idea imprecisa. Todos tenemos distintas cosmovisiones acerca de qué es vivir bien. Vivir bien puede significar vivir bajo ciertas condiciones materiales de existencia, aunque el modo de conseguirlas pueda ser algo indigno (como la mujer que permanece junto a su marido que le es infiel, para continuar disfrutando del nivel de vida socio-económico que tiene). Para otros, vivir bien es precisamente vivir dignamente y eso puede significar lograr metas o vivir gracias al sacrificio personal. Así, vivir a costa de otro es indigno o lo es el vivir por medios cuestionables (valga el dicho "pobre pero honrado"). Un ejemplo clásico es Sócrates, que puede ser el primero de los filósofos en hablar sobre vivir bien, en el Critón. Para él, huir de la cárcel, vivir como un prófugo refugiado en el exilio y defraudar las leyes que él tácitamente había aprobado toda su vida, es un ejemplo de vivir mal, ante lo cual precisamente es preferible la muerte. Por eso Sócrates acepta la cicuta. Otro ejemplo menos clásico lo vemos en la película The Matrix (de los hermanos Wachowski), cuando los protagonistas discuten qué es preferible: vivir en la verdad aunque sea de modo muy miserable, o vivir cómodamente conectado al mundo de fantasía que es la matrix. Esto tiene reminiscencias en la máquina de las experiencias de Nozick:

“[S]upongamos que existiera una máquina de experiencias que proporcionara cualquier experiencia que usted deseara. Neuropsicólogos fabulosos podrían estimular nuestro cerebro de tal modo que pensáramos y sintiéramos que estábamos escribiendo una gran novela, haciendo amigos o leyendo un libro interesante. Estaríamos todo el tiempo flotando dentro de un tanque, con electrodos conectados al cerebro. ¿Debemos permanecer encadenados a esta máquina por toda la vida, preprogramando las experiencias vitales? Si a usted le preocupa no haber tenido experiencias deseables, podemos suponer que empresas de negocios han investigado por completo las vidas de muchos otros. Usted puede encontrar y escoger de su amplia biblioteca o popurrí de tales experiencias y seleccionar 
sus experiencias vitales para, digamos, los próximos dos años. Una vez transcurridos estos dos años, usted tendría diez minutos o diez horas fuera del tanque para seleccionar las experiencias de sus próximos dos años. Por supuesto, una vez en el tanque usted no sabría que se encontraba ahí; usted pensaría que todo eso era lo que estaba efectivamente ocurriendo. Otros también pueden encadenarse y tener las experiencias que quieran, de modo que no hay necesidad de mantenerse fuera para servirlos. (Olvídese de problemas tales como ¿quién daría mantenimiento a las máquinas si todo el mundo estuviera encadenados a ellas) ¿Se encadenaría usted? ${ }^{28}$

Vivir bien es algo distinto para una persona religiosa, para un liberal, para un utilitarista, para un hedonista, etc ${ }^{29}$. Sostener que el derecho a la vida consiste en el derecho a vivir bien tornaría este derecho en inasible y por esa razón debemos rechazar esta concepción.

b) En segundo lugar, fácil es advertir que la dignidad y las condiciones materiales y espirituales de la existencia humana pueden no tener nada que ver con el Estado ni con la conducta de terceros. En ocasiones, pueden deberse exclusivamente a la propia conducta del sujeto. En tal caso, no podría hacerse responsable a terceros ni al Estado. En consecuencia, no tendría sentido en tal hipótesis decir que al titular se le ha vulnerado su derecho a la vida.

c) En tercer lugar, vivir bien -suponiendo que podemos definirlo- seguramente depende de una serie considerable de factores, que el Estado no puede asegurar. Por tanto, no puede constituir un derecho subjetivo público.

Como última observación me parece pertinente apuntar que cuando se confunde la vida con el objeto del derecho a la vida se cae en el error de pensar en la vida como realidad fenoménica y en las condiciones bajo las cuales sería posible vivir dignamente, o sobre qué ocurre cuando las condiciones materiales y espirituales no son las apropiadas. Esta concepción se acerca más a una ética de virtudes que al derecho. En cambio, si nos damos cuenta de que el objeto del derecho a la vida es la conducta de un tercero, entonces no hablaremos de vivir bien ni de los fines que debemos conseguir en nuestra vida sino de qué debe hacer o no hacer ese tercero. Esto sí es de incumbencia del ordenamiento jurídico. Por ello, debemos descartar esa perspectiva para referirnos al derecho a la vida.

28 Nozick, Robert. Anarquía, Estado y Utopía. Editorial Fondo de Cultura Económica. Traducción de Rolando Tamayo. México, 1978, pp. 53-54.

29 Sobre el tema de vivir bien, ver Dworkin, Ronald, EI Dominio de la Vida, Editorial Ariel, traducción de Ricardo Caracciolo y Víctor Ferreres, Barcelona, 1994, en la Sección "Muerte y vida", donde distingue intereses de experiencia e intereses críticos, para enfrentar la discusión de qué es vivir bien. 
Revisemos ahora la tercera concepción.

4.3. Existe una tercera concepción sobre el derecho a la vida, que no es mencionada por autores nacionales sino por Thomson. Se trata de aquella según la cual el derecho a la vida incluye tener derecho a que nos den aquello que mínimamente uno necesita para que la vida continúe. Dice esta autora: "In some views having a right to life includes having a right to be given at least the bare minimum one needs for continued life." 30 Así pues, si una persona está desfalleciendo de hambre y necesita, por ende, ingerir alimentos, su derecho a la vida comprende el derecho a recibir alimentos. O si está a punto de congelarse y la forma de evitarlo es permitiéndole entrar en mi casa, entonces su derecho a la vida comprende el derecho a entrar en mi casa.

Esta concepción tiene algún parecido con aquella según la cual la persona tiene derecho a vivir y seguir viviendo, pero no son idénticas, pues la concepción que ahora se explica no supone la inmortalidad.

Pues bien, cabe rechazar esta concepción sobre el derecho a la vida.

a) Un primer argumento lo da Thomson, que se pregunta ¿qué ocurre si el mínimo necesario que una persona necesita para seguir viviendo no tiene derecho a obtenerlo? Esa autora pone el ejemplo de Henry Fonda: puedo necesitar la fresca mano de Henry Fonda sobre mi afiebrada frente para salvarme pero no tengo derecho a ello ${ }^{31}$.

b) En segundo lugar, esta forma de entender el derecho a la vida permitiría pensar en innumerables situaciones en las cuales alguien tendría un derecho a recibir algo si con ello salvara su vida y, correlativamente, colocaría a las demás personas en innumerables situaciones de tener obligaciones frente a terceros. Esto ocurre porque esta perspectiva funda el derecho a la vida en la causalidad de mantención de la vida. El problema es que la causalidad atrapa a todas las personas que puedan salvar a alguien. Por ejemplo, es empíricamente comprobable que si voy a África ahora, voy a poder salvar a un niño de morir de hambre. Por tanto, si no lo hago, su muerte se va a producir inevitablemente y yo estaré vulnerando su derecho a la vida. Este es el conocido ejemplo de Singer y Unger ${ }^{32}$. En consecuencia, todas las personas que pudieran ayudar serían responsables de matar a los niños en África.

Thomson, J.J. “A defense of Abortion.” En Philosophy and Public Affairs. Vol 1, No. 1. 1971, p. 55.

Ibid.

A partir de este ejemplo, Peter Singer y Peter Unger pretenden fundar el deber moral de contribuir con dinero a organizaciones que salvan la vida, como Oxfam. Ver Peter Unger y el ejemplo del Bugatti en Living High and Letting Die, Oxford University Press, USA, 1996, y Peter Singer, "La solución de Singer a la pobreza del mundo", publicado en The New York Times Magazine y reproducido en español en Una vida ética. Escritos, Ed. Taurus. Madrid, 2002. 
Esta concepción basada en la causalidad diluye la idea de responsabilidad. En el ejemplo de los niños de África que mueren de hambre, es cierto que si yo voy salvo a algunos, pero también es cierto que si vas tú algunos niños también se salvan. Si ninguno va, ¿quién es responsable por esas muertes? Millones de personas lo serían, porque millones pueden ir y salvarlos. Esto es lo que yo llamo disolver la idea de responsabilidad. Hay que aclarar que aquí estoy hablando de responsabilidad "jurídica" y no moral, porque es perfectamente admisible sostener la idea de que millones de personas tenemos responsabilidad moral respecto del destino de millones de personas más. El ejemplo de Singer y Unger ${ }^{33}$ está destinado a fundar la idea de responsabilidad moral, no jurídica. La humanidad es responsable moralmente de lo que ocurre en el planeta que sea atribuible a sus propias decisiones. Pero de lo que trata aquí es de fundar responsabilidades jurídicas ${ }^{34}$.

c) En tercer lugar, debe rechazarse esta amplísima concepción del derecho a la vida porque equipara derecho a la vida con la salud ${ }^{35}$; no con el derecho a la salud sino un supuesto derecho a estar sano o a sanarse. Supongamos que estoy muriendo de cáncer y para salvarme necesito un transplante de médula en USA. Un empresario multimillonario podría pagar esa operación sin gran sacrificio para él. Entonces, si él no lo hace, sería responsable de mi muerte. Muchas personas pueden pagar los tratamientos médicos o remedios que otros necesitan para no morirse en lo inmediato. Conforme esta visión del derecho a la vida, todas esas personas que podrían salvar a otros serían jurídicamente responsables de la muerte de los enfermos. La ampliación de la idea de responsabilidad lleva a la ampliación del concepto de derecho a la vida en el sentido de que comprendería el derecho a estar sano. Pues bien, no existe un derecho a estar sano. El derecho a la salud no se entiende de esa manera pues no es algo que el Estado pueda asegurar. Las personas en ocasiones inevitablemente enferman y a veces mueren por ello sin que nadie haya hecho ni pueda hacer nada al respecto. Por ende, nadie tiene la obligación de asegurar la salud o el restablecimiento de ella para un tercero ni evitar que muera. Por estas consideraciones debe rechazarse esta amplísima forma de entender el derecho a la vida.

\footnotetext{
33 Ver cita precedente.

34 A propósito de responsabilidades jurídicas, podemos considerar la omisión de socorro, recogida por el artículo $494 n^{\circ} 14$ del Código Penal, que dispone: "El que no socorriere o auxiliare a una persona que encontrare en despoblado herida, maltratada o en peligro de perecer, cuando pudiere hacerlo sin detrimento propio." Como se puede advertir, esta norma requiere que el sujeto eventualmente responsable se encuentre en el lugar donde yace el necesitado. Por eso, esta norma no nos sanciona por no ir a África a salvar niños hambrientos. Y respecto del caso hipotético de una persona que se encontrara fuera de mi casa, y corriere el riesgo de morir congelada, no quedaría comprendido por esta norma, debido a que requiere que una persona encuentre a otra en despoblado.

35 En los casos de VIH-Sida del año 1999, se presentó a la corte un argumento según el cual el derecho a la salud comprende el derecho a recibir lo necesario para no morir.
} 
4.4. Una cuarta concepción sostiene que el derecho a la vida consiste en el derecho a que no me maten. En la doctrina nacional no se advierten autores que abiertamente y de modo directo suscriban esta postura, cuando explican en qué consiste el derecho a la vida. Sin embargo, la situación cambia cuando se refieren a la situación del nasciturus. La mayoría de la doctrina nacional sostiene que el nasciturus es persona ${ }^{36}$, tiene derecho a la vida y está protegido por la Constitución ${ }^{37}$. En consecuencia, para la

36 Por ejemplo, Corral, Hernán. “Admisibilidad jurídica de las técnicas de procreación artificial.” En Revista Chilena de Derecho, Vol. 19, 1992. pp. 447, 449; Zapata, Patricio. "Persona y embrión humano. Nuevos problemas legales y su solución en el derecho chileno.” En Revista Chilena de Derecho, Vol. 15, 1988, pp. 376, 378; Evans, Enrique. Los Derechos Constitucionales, ob. cit, p. 113; Ugarte, José. EI Derecho de la vida. Editorial Jurídica de Chile, Santiago, 2006, pp. 117ss, 235, 258; el mismo autor, en "Momento en que el embrión es persona humana", en Estudios Públicos, 96 (primavera), Santiago, 2004; Silva, Jaime. "El nasciturus y el derecho a la vida", en Revista de Derecho Público, nº 57/58, enero-diciembre, Santiago, 1995, p. 186; Varela, Jorge. "Derechos Humanos y Aborto", en Revista de Derecho Público, nº 47/48, enero-diciembre, Santiago, 1990, p. 197; Vivanco, Angela. Curso de Derecho Constitucional. ob. cit, p. 244; Soto, Eduardo. "La noción de persona en la Constitución", en Revista de Derecho Público, n 50, julio-diciembre, Santiago, 1991, p. 139; Fermandois, en Fermandois, Arturo. "La píldora del día después: aspectos normativos" en Estudios Públicos, 95 (invierno), Santiago, 2004, p. 101; Cea, José. Derecho Constitucional Chileno, ob. cit, p. 46.

37 Por ejemplo, Corral sostiene que el embrión debe estar protegido desde la concepción porque desde ese momento hay vida humana. Ver Corral, Hernán. "Admisibilidad jurídica de las técnicas de procreación artificial." ob. cit, p. 450. En la misma línea, Evans: [T]odo ser humano tiene el derecho esencial de conservar su vida y de exigir que el ordenamiento jurídico se la proteja contra atentados de la autoridad y de particulares." Evans, E. Los Derechos Constitucionales, ob. cit, p. 113. También Fermandois, A; ob. cit, p. 101. También Carrasco, Sergio. "La garantía constitucional del derecho a la vida del que está por nacer." XVIII Jornadas Chilenas de Derecho Público. Concepción, 1987. También Silva, J., ob. cit, p. 186; también Soto, E. "Derecho a la vida y recurso de protección", Revista de Derecho y Jurisprudencia y Gaceta de los Tribunales, Tomo LXXXI, No 2, MayoAgosto, Santiago, 1984, Primera Parte, p. 60; también Fermandois, A., ob. cit, p. 101. Por su parte, Nogueira concuerda en que el nasciturus es sujeto de derecho y es persona. Nogueira, Humberto. "El derecho a la vida en el ordenamiento jurídico chileno." Gaceta Jurídica, No 207, 1997, pp. 9-10. También Zapata, P. "Persona y embrión humano. Nuevo problemas legales y su solución en el derecho chileno.” ob. cit, p. 382. Agrega: si la constitución establece un mandato de proteger al que está por nacer, en el art. $19 \mathrm{~N}^{\mathrm{o}} 1$, es porque el embrión es una persona que tiene derecho a la vida. p. 383, pp. 386 ss. Otro ejemplo es Evans: [L]a vida, por ser el don primario que Dios ha dado al hombre, y por ser fuente de sus demás atributos, está cautelada por la institucionalidad constitucional y legal desde que se inicia la gestación.” Evans, ob. cit, p. 113. Otro autor dice: “...naturalmente, el nasciturus es titular de este derecho en la misma forma que lo son todas las demás personas.” Silva, J. ob. cit, p. 193. Otro autor en el mismo sentido: "[R]especto de ningún otro sujeto de derecho es posible concebir una mayor propiedad en el lenguaje que "el derecho a la vida" de la criatura que está en el vientre materno. Es ella la que por excelencia tiene un derecho adquirido a vida intrauterina desde la concepción o fecundación." Varela, J. ob. cit, p. 197. Soto Kloss, por su parte, lo dice de manera categórica: "El que está por nacer es persona. La Constitución le asegura el derecho a la vida, como también lo asegura a quien ya ha nacido. No hay diferencia de tratamiento entre uno y otro ya que ambos son individuos de la especia humana, y sería una diferencia arbitraria, sin justificación racional pretender discriminar en cuanto al derecho a vivir, al derecho a la vida..." Soto, E. "El derecho a la vida y la noción de persona en la Constitución." Revista de Derecho y Jurisprudencia y Gaceta de 
mayoría de la doctrina nacional el aborto se encuentra prohibido siempre por la carta fundamental ${ }^{38}$.

Pues bien, si conforme esa doctrina mayoritaria el aborto se encuentra prohibido siempre en atención a que el nasciturus es persona y tiene derecho a la vida, eso significa que el derecho a la vida del nasciturus se entiende como no matar nunca, de modo absoluto. En consecuencia, tratándose del nasciturus, la mayoría de la doctrina nacional entiende el derecho a la vida como el derecho a que no lo maten.

Esta noción del derecho a la vida es analizada por Thomson ${ }^{39}$. Debe destacarse que esta postura es evidentemente más restringida que la anterior pues no genera obligaciones positivas de mantención de mi vida para millones de personas; sólo impone sobre todos la obligación negativa de no matar. En este sentido, se acerca a la concepción más estricta que he presentado al comenzar - no matar arbitrariamente- pero se diferencia de ella en cuanto no incluye la cláusula de arbitrariedad. Según esta cuarta concepción, la obligación que recae sobre terceros consiste simplemente no matar.

¿Es aceptable esta cuarta concepción sobre el derecho a la vida? En la medida en que no incluye la cláusula de no arbitrariedad, la respuesta es negativa. Entender que el derecho a la vida siempre prohibe matar a otro lo transforma en un derecho absoluto, pues en ninguna circunstancia una persona podría matar a otra. ¿Qué problema hay en entenderlo como un derecho absoluto? ${ }^{40}$ El problema obvio es que excluiría matar a otro en legítima defensa, de modo que una persona bajo ataque debería dejarse matar aunque pudiera defenderse. Nadie

los Tribunales. Tomo LXXXVIII, № 3, 1991, Primera parte, p. 59; Nogueira, Humberto. El Derecho a la Vida, ob. cit, p. 205 entre otras páginas.

38 Por ejemplo, Precht, Jorge. "Consideraciones ético-jurídicas sobre el aborto terapéutico.” En Revista Chilena de Derecho, Vol. 19, 1992, pp. 516-521. A él hay que sumar todos los autores citados en las dos notas precedentes.

39 Ver Thomson, op. cit, pp. 55-56.

40 Existen diferentes formas de entender la idea de derecho absoluto. Una forma muy vaga de entenderlo es aquella según la cual un derecho es absoluto cuando no admite excepciones, o no se puede suspender, o no puede ser limitado por la ley o el titular jamás puede ser privado de él. En este sentido vago, la libertad de conciencia podría ser un derecho absoluto porque jamás el ordenamiento jurídico permite privar a alguien de ella. El derecho a no ser torturado también lo sería porque no puede suspenderse ni limitarse. Hay derechos procesales que también podrían considerarse absolutos, como el derecho a un tribunal independiente e imparcial, el derecho a no declarar contra sí mismo, etc. Por la inversa, serían derechos relativos el derecho a la privacidad, el derecho a la libertad personal, etc, porque el titular puede ser privado de ellos, o se pueden limitar por ley, o establecer excepciones. Otra forma de entender el carácter absoluto o relativo de los derechos es si ellos están sometidos a ponderación. Alexy sostiene que en este sentido no existen derechos absolutos, lo que constituye un punto en contra de esta cuarta concepción del derecho a la vida. 
(salvo un jainista) está dispuesto a entender el derecho a la vida de ese modo. En efecto, en la doctrina nacional, todos aceptan matar a otro en legítima defensa, y muchos aceptan la pena de muerte. Probablemente ningún sistema jurídico del mundo entiende que las personas deberían dejarse matar para evitar cometer un homicidio al defender su propia vida.

Thomson analiza esta concepción utilizando el famoso ejemplo del violinista: una persona $\mathrm{X}$ despierta en una cama de hospital y se da cuenta que está conectada, a través de sus riñones, a un famoso violinista que necesita diálisis. Miembros de la Sociedad de Amantes de la Música raptaron a $\mathrm{X}$ durante la noche porque era la única persona cuya sangre era compatible con la del violinista. No cabe duda que el rapto y posterior conexión son actos ilegales incluso criminales, y X podría desconectarse sin daño para él, pero hacerlo mataría al violinista. El argumento es el siguiente: si creemos que el derecho a la vida del violinista significa llanamente el derecho a que no lo maten, entonces $\mathrm{X}$ no tendría derecho a desconectarse porque eso violaría el derecho a la vida del violinista ${ }^{41}$. Que $\mathrm{X}$ se resigne a vivir conectado al violinista por el tiempo que sea necesario tampoco resuelve el problema: podría ser el caso que la carga extra para los riñones de $\mathrm{X}$ pusiera en peligro su vida si no se desconecta a la brevedad. Sin embargo, de todos modos $\mathrm{X}$ no podría hacerlo porque el violinista tiene derecho a la vida. En consecuencia, $\mathrm{X}$ debería dejarse morir. Por estas consideraciones, Thomson rechaza esta concepción del derecho a la vida y adhiere a la sencilla idea de que el derecho a la vida implica el derecho a no ser muerto arbitrariamente ${ }^{4243}$.

Es posible pensar que la mayoría de la doctrina nacional adhiere a una concepción absoluta del derecho a la vida del nasciturus porque tal vez piense que respecto de él nunca podría existir una causal de justificación para matarlo. Como sabemos, los casos que más frecuentemente se citan en que se justifica matar a alguien contra su voluntad son legítima defensa y aplicando una pena de muerte (según el artículo $19 \mathrm{n}^{\circ} 1$ de la Constitución). Pues bien, es obvio que respecto del nasciturus nunca serían aplicables estas justificaciones. Entonces, quizá por esto la mayoría de al doctrina nacional considere que al nasciturus no se le puede matar nunca. Es difícil saber si la mayoría de la doctrina nacional piensa en verdad aquello, porque los autores no explican por qué al nacido le confieren un derecho a la vida relativo y al nasciturus un derecho a la vida absoluto. Pero podemos considerarlo como hipótesis. De ser así, cabría comentar lo siguiente:

Thomson, ob. cit, p. 55.

Ibid, p. 57.

Bascuñán también rechaza una concepción absoluta del derecho a la vida, ver Bascuñán, Antonio. "La píldora del día después ante la jurisprudencia.” En Estudios Públicos, 95, Santiago (invierno 2004), pp. 67ss. 
i) Esa perspectiva es errada porque el nasciturus no tiene derecho a la vida, por tanto, no tiene sentido pensar si ese derecho es absoluto o no $^{44}$.

ii) No parece razonable suscribir una concepción del derecho a la vida que se desdobla en dos, dependiendo del supuesto titular: si ha nacido, su derecho es relativo y si no ha nacido, su derecho es absoluto. Los derechos constitucionales deben significar lo mismo para todas las personas ${ }^{45}$.

iii) Suponiendo, sólo para efectos de la discusión, que el nasciturus tuviera derecho a la vida, es posible reconstruir dogmáticamente otras hipótesis de justificación aplicables a él, distintas de la legítima defensa o la pena de muerte. Por ejemplo, el estado de necesidad defensivo, como hace la doctrina penal alemana. Tratándose del nasciturus, Roxin admite expresamente el estado de necesidad en la forma que él llama perforación, que consiste en matar al niño para salvar a la madre. ${ }^{46}$

iv) Suponiendo -igualmente- que el nasciturus tuviere derecho a la vida es necesario recordar que nunca es aceptable, desde el punto de vista de la dogmática constitucional, que un derecho sea absoluto, en el entendido -como dice Alexy- que no admita ponderación frente a otros derechos ${ }^{47}$. En efecto, en el único caso de la jurisprudencia constitucional comparada en que se ha reconocido que el nasciturus es titular del derecho a la vida (que es el caso alemán), se ha declarado que su derecho a la vida no es absoluto y la corte constitucional ha señalado que hay varias hipótesis en las cuales se justifica el aborto. Se trata de hipótesis que la corte consideró correspondían a situaciones de inexigibilidad para la mujer de continuar el embarazo: razones eugenésicas (malformaciones), éticas (criminológicas, como embarazo por violación), sociales (pobreza), entre otras, dijo el tribunal en un el fallo 39 BverGe I, de $1975^{48}$. Luego, la corte agregó la hipótesis de grave conflicto

44 En un artículo titulado "Concepto de persona, Titularidad del Derecho a la Vida y Aborto" he presentado las razones para entenderlo así.

45 La única excepción reconocida en el derecho constitucional comparado es el derecho a la privacidad, que asume una fisonomía distinta dependiendo de si el titular es un funcionario público, un particular o posiciones intermedias.

46 Ver Roxin, Claus. Derecho Penal. Parte General. Tomo 1. Trad. de Diego-Manuel Luzón Peña, Miguel Díaz y García Conlledo y Javier de Vicente Remesal. Ed. Civitas. 1997, reimp. 2001. p. 705.

$47 \quad$ Ver Alexy, ob. cit, p. 291.

48 Ver la sentencia 39 BverGe I, de 1975. En ella, dijo el tribunal:

"Unzumutbar erscheint die Fortsetzung der Schwangerschaft insbesondere, wenn sich erweist, daß der Abbruch erforderlich ist, um von der Schwangeren "eine Gefahr für ihr Leben oder die Gefahr einer schwerwiegenden Beeinträchtigung ihres Gesundheitszustandes abzuwenden” ( $\$ 218$ b Nr. 1 StGB in der Fassung des Fünften 
psicológico o social de la mujer que claramente constituya una carga no razonable, en el fallo 88 BVerfge203, de $1993^{49}$.

Por tanto, no es aceptable suscribir una concepción del derecho a la vida de carácter absoluto, para nadie, incluyendo al nasciturus.

Concluyo esta sección reiterando que la única forma razonable de entender el derecho a la vida es como el derecho a que no nos maten arbitrariamente.

\section{Disponer de la propia vida.}

Algunos autores nacionales incluyen dentro del objeto del derecho a la vida la conducta del titular y ella consistiría en que el titular no podría disponer de su propia vida. Así, por ejemplo, dicen que el suicidio no estaría permitido ni tampoco la eutanasia. Señala un autor:

Strafrechtsreformgesetzes). In diesem Fall steht ihr eigenes "Recht auf Leben und körperliche Unversehrtheit" (Art. 2 Abs. 2 Satz 1 GG) auf dem Spiel, dessen Aufopferung für das ungeborene Leben von ihr nicht erwartet werden kann. Darüber hinaus steht es dem Gesetzgeber frei, auch bei anderen außergewöhnlichen Belastungen für die Schwangere, die unter dem Gesichtspunkt der Unzumutbarkeit ähnlich schwer wie die in $\S 218 \mathrm{~b}$ Nr. 1 angeführten wiegen, den Schwangerschaftsabbruch straffrei zu lassen. Hierzu können insbesondere die in dem in der 6. Wahlperiode des Bundestages vorgelegten Entwurf der Bundesregierung enthaltenen und sowohl in der öffentlichen Diskussion wie auch im Verlauf des Gesetzgebungsverfahrens erörterten Fälle der eugenischen (vgl. $\S 218 \mathrm{~b} \mathrm{Nr}$. 2 StGB), der ethischen (kriminologischen) und der sozialen oder Notlageindikation zum Schwangerschaftsabbruch gezählt werden. Bei den Beratungen des Sonderausschusses für die Strafrechtsreform (7. Wp., 25. Sitzung, StenBer. S. 1470 ff.) hat der Vertreter der Bundesregierung ausführlich und mit überzeugenden Gründen dargelegt, warum in diesen vier Indikationsfällen die Austragung der Schwangerschaft nicht als zumutbar erscheint. Der entscheidende Gesichtspunkt ist, daß in allen diesen Fällen ein anderes, vom Standpunkt der Verfassung aus ebenfalls schutzwürdiges Interesse sich mit solcher Dringlichkeit geltend macht, daß die staatliche Rechtsordnung nicht verlangen kann, die Schwangere müsse hier dem Recht des Ungeborenen unter allen Umständen den Vorrang einräumen." Sección C.III.3. 3er párrafo del fallo.

49 Caso 88 BVerfge203, de 1993. Allí la corte constitucional alemana sostuvo:

"Für die Pflicht zum Austragen des Kindes folgt daraus, daß neben der hergebrachten medizinischen Indikation auch die kriminologische und - ihre hinreichend genaue Umgrenzung vorausgesetzt - die embryopathische Indikation als Ausnahmetatbestände vor der Verfassung Bestand haben können; für andere Notlagen gilt dies nur dann, wenn in ihrer Umschreibung die Schwere des hier vorauszusetzenden sozialen oder psychisch-personalen Konflikts deutlich erkennbar wird, so daß - unter dem Gesichtspunkt der Unzumutbarkeit betrachtet - die Kongruenz mit den anderen Indikationsfällen gewahrt bleibt.” Extracto de la sección D.2. (c) (bb) del fallo. De este párrafo se colige que, además de las hipótesis de indicación médica, criminológica o embriopática que pueden justificar el aborto, podría haber otras situaciones en las cuales el aborto también se justifique, como un caso de grave conflicto psicológico o social de la mujer, que claramente constituya una carga no razonable. 
"[T] odo ser humano tiene el derecho esencial de conservar su vida (...) El enfermo tiene, también, derecho a que se preserve su vida y, por tanto, a las técnicas médicas necesarias, sin que sea admisible ninguna forma de eutanasia. ${ }^{50}$

Un poco más adelante, el mismo autor sostiene:

"El derecho a la vida (...) impone, además, dos obligaciones: a) La de respetar la propia vida, por lo cual la ley penal sanciona la tentativa de suicidio, ..."

Otro autor lo dice del siguiente modo:

"El derecho a la vida constituye un bien jurídico constitucional objetivo y un derecho de defensa, no disponible por la persona..." 52

Más adelante agrega:

"Que el derecho a la protección de la vida sea un derecho de carácter individual y de defensa, no lo convierte en un derecho de libertad o de libre disposición..."53

Esta postura ha sido recogida por alguna jurisprudencia a propósito de las huelgas de hambre $^{54}$. Dijo la Corte de Apelaciones:

“...es de derecho natural que el derecho a la vida es el que tenemos a que nadie atente contra la nuestra, pero de ningún modo consiste en que tengamos dominio sobre nuestra vida misma, en virtud del cual pudiéramos destruirla si quisiéramos, sino en la facultad de exigir de los otros la inviolabilidad de ella. Es lo que expresa don Rafael Fernández Concha en el Tomo III de su obra sobre Filosofía del Derecho, al insistir en que el derecho de vida, "no consiste ni se funda en dominio directo sobre la vida, por cuanto tal dominio no lo tiene ningún hombre, respecto de la propia". En efecto, el dominio importa necesariamente una relación entre un sujeto y un objeto diferente, en tanto que el hombre y su vida se identifican y son una misma cosa;" $\left(\mathrm{C}^{\mathrm{o}} 10\right)$.

Evans, ob. cit. p. 113.

Ibid, p. 114.

Nogueira, Humberto, ob. cit, p. 49.

Ibid.

Recurso de protección rol 167-84, de 1984, huelga de hambre de estudiantes de la Universidad Católica. 
Continúa la corte en el $\mathrm{C}^{\mathrm{o}} 11$ :

"11.- Que, por otra parte, la inviolabilidad de la vida por uno mismo, o por otra persona, es fruto de la civilización judeo-cristiana, que ha inspirado toda nuestra legislación y ha sido recogida invariablemente por la Teología y el Derecho Natural, ya sea en sus corrientes tomistas o racionalistas. Como expresa Etcheberry en su aludida obra de Derecho Penal "la integridad corporal y la salud no constituyen bienes disponibles" (página 114, tomo III), de donde se desprende que todo atentado en contra de estos bienes, es, por decir lo menos, arbitrario e injusto; y..."

En casos posteriores de huelgas de hambre se ha mantenido la misma doctrina, que la vida es indisponible por parte del sujeto ${ }^{55}$.

En este trabajo no discutiremos los casos en que se puede matar a otro de modo justificado, con o sin su consentimiento y, por ende, no revisaremos la eutanasia, el auxilio al suicidio, el estado de necesidad defensivo, etc. Solamente tocaremos el caso de disponer de la vida porque -como acabamos de ver- en alguna literatura nacional y en alguna jurisprudencia se ha considerado que la conducta del titular está regulada por este derecho.

Esta postura que siguió la Corte de Apelaciones y también algunos autores de la doctrina nacional cuenta con algún respaldo en cierta la literatura, que ofrece los siguientes argumentos:

5.1. Se puede citar la tesis de que la vida pertenece al Estado. Si la vida pertenece al Estado, entonces el individuo no puede disponer de ella. Esta es una visión de la sociedad que ha tenido algún correlato empírico ${ }^{56}$.

5.2. Se ha sugerido también el argumento del perjuicio para terceros: el sujeto que se quita la vida cesa sus contribuciones económica, intelectual, afectiva, etc, a otros y a la sociedad en su conjunto ${ }^{57}$.

55 Por ejemplo, los casos de huelga de trabajadores de Codelco, rol 3569-86, Corte de Apelaciones de Copiapó; huelga de trabajadores del Diario La Época, rol 1561-92, Corte de Apelaciones de Santiago, etc.

$56 \quad$ Nino cita el caso de las leyes de Eduardo El Confesor en Inglaterra, siglo XI, o la memoria de la comisión nazi de reforma del Código Penal alemán. Ver Ética y Derechos Humanos. Editorial Paidós. Buenos Aires, 1984. p. 286.

$57 \quad$ Ver Nino, ibid. 
5.3. El argumento kantiano. Dice este autor: “...conservar la propia vida es un deber..."58. Luego agrega:

“Un hombre, que por una serie de desgracias rayanas en la desesperación, siente desapego por la vida, tiene aún suficiente razón como para preguntarse si no será contradictorio al deber para consigo mismo quitarse la vida. Pruebe a ver si la máxima de su acción puede convertirse en ley universal de la naturaleza. Su máxima es me hago, por egoísmo, el principio de abreviar mi vida cuando esta, a la larga, me ofrezca más males que bienes. Se trata ahora de saber si tal principio egoísta puede ser una ley universal de la naturaleza. Muy pronto se ve que una naturaleza cuya ley fuese destruir la vida misma mediante el mismo impulso encargado de conservarla sería, sin duda alguna, una naturaleza contradictoria y que no podría subsistir. Por lo tanto, aquella máxima no puede realizarse como ley natural universal y, en consecuencia, contradice por completo al principio supremo de todo deber." 59

Nino pone los argumentos de Kant del siguiente modo: El suicidio no es compatible con la máxima ética de la universalización porque es autocontradictorio: el suicidio está determinado por un sentimiento egoísta de autoestima cuyo fin no es destruir sino fomentar la vida, con lo que frustra el fin del propio sentimiento que lo motiva. Además pugna con el principio de tratar a la humanidad siempre como un fin y no sólo como un medio, porque el suicida se toma sí mismo como un medio ${ }^{60}$.

5.4. El argumento religioso. Este argumento sostiene que la vida le pertenece al Creador. El individuo no puede disponer de su vida porque ella no le pertenece, sino al creador.

Un argumento de este tipo lo encontramos en algunos autores clásicos. Por lo pronto, en El Fedón:

“- Entonces, Sócrates, ¿en qué se basan los que dicen que no es lícito darse muerte a sí mismo? Porque yo, como tú me preguntabas hace un momento, ya lo oí decir a Filolao, cuando vivía entre nosotros, y a algunos otros, que no se debía hacer eso. Pero algo definitivo sobre ello jamás le he oído a nadie.

Kant, Immanuel. Fundamentación de la Metafísica de las Costumbres, colección austral, edición de Luis Martínez de Velasco, Madrid, novena edición, 1990, p. 59.

$59 \quad$ Ibid, p. 93.

$60 \quad$ Nino, Ética, ob. cit, p. 287. 
-Pues es menester no desalentarse - dijo- porque tal vez lo podrías oír. Sin embargo, quizá te parecerá extraño que sea la única cuestión simple entre todas y que jamás se presente al hombre como las demás. Hay casos, sí, e individuos para quienes mejor les sería estar muertos que vivir, pero lo que tal vez parezca chocante es que para esos individuos, para quienes vale más estar muertos, sea una impiedad el hacerse ese beneficio a sí mismos, y tengan que esperar a que sea otro su bienhechor.

(...)

En efecto -prosiguió Sócrates- desde este punto de vista puede dar la impresión de algo ilógico. Sin embargo, no lo es y tal vez tenga alguna explicación. Y a propósito, lo que se dice en los misterios sobre esto, que los hombres estamos en una especie de presidio, y que no debe liberarse uno a sí mismo ni evadirse de él, me parece algo grandioso y de difícil interpretación. Pero lo que sí me parece, Cebes, que se dice con razón es que los dioses son quienes cuidan de nosotros y que nosotros, los hombres, somos una de sus posesiones. ¿No te parece así?”

-A mí, sí-respondió Cebes." ${ }^{\prime 1}$

También es conocida la postura de Locke sobre el particular:

“...siendo todos los hombres iguales e independientes, ninguno debe dañar a otro en lo que atañe a su vida, salud, libertad o posesiones. Pues como los hombres son todos obra de un omnipotente e infinitamente sabio Hacedor, y todos siervos de un señor soberano enviado a este mundo por orden suya y para cumplir su encargo, todos son propiedad de quien los ha hecho, y han sido destinados a durar mientras a El le plazca, y no a otro. Y así, habiendo sido todos los hombres dotados con las mismas facultades, y al participar todos de una naturaleza común, no puede suponerse que haya entre nosotros una subordinación que nos dé derecho a destruir al prójimo como si este hubiese sido creado para nuestro uso, igual que ocurre con esas criaturas que son inferiores a nosotros. Por la misma razón que cada uno se ve obligado a preservarse a sí mismo y a no destruirse por propia voluntad, también se verá obligado a preservar al resto de la humanidad en la medida en que le sea posible,..."62

61 Platón, Fedón. Sección 62 a), b) y c). Tomado de la edición de Alianza Editorial, Madrid, 1995.

62 Locke, John. Segundo Tratado sobre el Gobierno Civil. Capítulo 2, sección 6. En la edición de Alianza Editorial, Madrid, 1990, ver p. 38. 
En Chile, el más reciente ejemplo de posturas fundadas en el magisterio de la Iglesia y con recurrentes referencias a Dios es el texto de $\mathrm{Ugarte}^{63}$. Si bien es cierto que Ugarte menciona el nombre de Platón, Aristóteles ${ }^{64}$, Kant, Locke, entre otros, cuando alude al suicidio, lo concreto es que los argumentos que desarrolla en las 6 páginas que dedica en su libro al suicidio los toma de Aquino y Fernández Concha, este último basado en el magisterio de la Iglesia Católica. El argumento central de Ugarte es teológico. Dice que el suicidio es:

“...intrínsecamente ilícito, contrario a la moral, porque no tenemos el dominio sino sólo el usufructo, por sí decir, de nuestra propia vida; no podemos disponer de ella, desde que, como más arriba se dijo, por una parte, Dios es el señor o dueño de la vida..." ${ }^{65}$

A continuación, revisaremos estos cuatro argumentos contra la disposición de la vida:

\section{La tesis de que la vida pertenece al Estado.}

No es mucho que lo vale la pena decir de este argumento, porque difícilmente alguien deseará suscribirlo. En efecto, no resulta sencillo entusiasmarse con un principio totalitario que tuvo correlato empírico en el régimen nazi. ${ }^{66}$ Además, es fácil advertir que este no es un argumento, pues no hay razones, sino más bien es una petición de un principio.

\section{El argumento del daño a terceros.}

Se dijo que quien se quita la vida deja de contribuir a los suyos y a la sociedad en su conjunto y eso genera un daño. Este argumento tiene dificultades. Por lo pronto, se trata de un

63 Ugarte, José. El Derecho a la Vida, ob. cit.

64 Respecto de Platón y Aristóteles, resulta curioso que Ugarte los cite para apoyar su postura sobre el derecho a la vida, considerando que esos autores justifican el aborto, entre otras cosas que ciertamente Ugarte no comparte. Sobre el aborto, ver Platón, La República, 461c (en la edición de Alianza Editorial, 1988, traducción de José Manuel Parbón y Manuel Fernández-Galiano, ver la p. 282); Aristóteles, La Política, 1335b 15 (en la versión de la Editorial Gredos, traducción de Manuela García Valdés, 1988, ver las pp. 447-448).

Por otra parte, citar a Platón y Aristóteles para elaborar dogmática de derechos constitucionales es absurdo. En la época de estos clásicos no habría tenido sentido pretender que el sujeto se constituyera como un individuo con derechos frente al Estado, que reclamara espacios de autodeterminación sin injerencia estatal. La sola idea de derechos fundamentales supone la distinción entre lo público y lo privado, distinción inadmisible en Grecia clásica. La idea de derechos fundamentales, tal como los entendemos en la actualidad, es una consecuencia del constitucionalismo, que es una tradición moderna del todo ajena a la concepción griega clásica.

65 Ugarte, ob. cit, p. 183.

66 Ver Nino, ob. cit, p. 286. 
argumento de carácter relativo, porque no en todos los casos una persona está en condiciones de contribuir a la sociedad. En aquellos casos, el argumento no funciona.

En segundo lugar, y suponiendo que una persona en verdad puede contribuir a la sociedad, debe considerarse lo siguiente: si se tienen en cuenta los intereses de terceros y de la sociedad, también deben sopesarse los intereses del sujeto. Dado que el individuo pretende adoptar tan drástica decisión, es dable suponer que sus intereses son especialmente fuertes, lo que exige entonces ser cautelosos frente al peso que pueden tener los intereses de terceros. ${ }^{67}$

En tercer lugar, el daño que se produciría según este argumento sería consecuencia de una omisión. Pues bien, sostiene Nino, “...la adscripción causal de efectos nocivos a las omisiones requiere una fuerte expectativa justificada de actuación positiva..." ${ }_{68}$, lo que puede darse respecto de dependientes inmediatos, pero no puede proyectarse a la sociedad ilimitadamente.

En cuarto lugar, Hume se ha detenido a refutar la idea de la contribución social:

"Un hombre que se retira de la vida no hace daño alguno a la sociedad; lo único que hace es dejar de producirle bien. Y si esto es una ofensa, es, ciertamente, de la más modesta especie. Todas nuestras obligaciones de hacer bien a la sociedad parecen implicar algún beneficio recíproco. Yo recibo beneficios de la sociedad, y por lo tanto me veo obligado a promover sus intereses. Pero cuando yo me aparto totalmente de ella, ¿podré estar siguiendo atado a esas obligaciones? Aun suponiendo que nuestro deber de hacer el bien fuese un deber perpetuo, tiene que haber por fuerza un límite. No estoy obligado a hacer un pequeño bien a la sociedad, si ello supone un gran mal para mí. ¿Por qué debo, pues, prolongar una existencia miserable sólo porque el público podría recibir de mí alguna minúscula ventaja? $\mathrm{Si}$ a causa de la edad o de enfermedades me está legalmente permitido jubilarme de cualquier empleo y utilizar todo mi tiempo en combatir esas calamidades y en aliviar en lo posible las molestias de la vida que me quede, ¿por qué no ha de estarme permitido acabar de una vez por todas con esos sufrimientos llevando a cabo una acción que no es más perjudicial para la sociedad? Pero supongamos que ya no tengo el poder de promover los intereses de la sociedad; supongamos que me convierto en una carga para ella; supongamos que el hecho de permanecer vivo está impidiendo a otra persona ser mucho más útil a la sociedad. En casos así, mi renuncia a la vida no sólo sería un acto inocente, sino también laudable." ${ }^{69}$

Ibid, p. 286.

Ibid.

Hume, D. Sobre el suicidio y otros ensayos. Alianza Editorial. Madrid, 1995, p. 131-132. 
Por tanto, este argumento requiere fundar deberes positivos, lo que siempre es muy complejo ${ }^{70}$; además es posible que el sujeto no sea capaz de producir ninguna contribución a la sociedad y peor aún, que el sujeto sea una carga para ella. En estos casos, el argumento del perjuicio no funciona. Respecto de los otros casos, el argumento tiene límites pues hay casos en que no es aplicable (una persona que no tiene dependientes, o un enfermo terminal que morirá pronto y que no está contribuyendo a la sociedad, etc). Por tanto, el argumento del perjuicio a terceros no es concluyente.

\section{El argumento kantiano.}

Se dijo que para Kant el suicidio no es compatible con la máxima ética de la universalización porque es autocontradictorio. Además, pugna con el principio de tratar a la humanidad siempre como un fin y no sólo como un medio. Estos argumentos de Kant no parecen concluyentes, dice Nino. Respeto del primer argumento, señala este autor:

“...puede haber circunstancias en que el suicidio no implique una actitud de desprecio hacia la vida que sea incompatible con el supuesto fin del sentimiento de autoestima (como el caso de quien se suicida para evitar una muerte cierta a través de terribles torturas). En segundo término, no es claro que sea moralmente relevante si la función "natural" del sentimiento de autoestima es o no la de fomentar la vida (...)... por último, no todo suicidio está motivado por un sentimiento de autoestima." (el caso de quien se suicida para que su familia cobre un seguro de vida). "En relación con el segundo argumento, no es obvio por qué el que decide libremente quitarse su vida está usando su persona como un mero medio. En todo caso (...) Kant es aquí incoherente pues admite, sobre la base del consentimiento, la legitimidad del duelo determinado por motivos de honor."’1

En mi opinión, el argumento de Kant de que el suicida se trata a sí mismo como un medio, no hace mucho sentido. Más bien, me parece que sucede lo contrario. Quien sostiene que la vida es indisponible por parte del individuo, está colocando a la vida como un fin en sí mismo, con prescindencia del sujeto que la porta. El individuo que seriamente desea terminar con su vida, tiene razones que él considera sumamente relevantes para hacerlo. Si no debe hacerlo por consideración a un fin en sí mismo, como es la vida, entonces él se pone al servicio de ese fin, con lo cual él se coloca como un medio. Cuando la sociedad prohíbe el suicidio, coloca a las personas al servicio de este fin último, y eso parece una instrumentalización que contradice la

Garzón, Ernesto. “Los deberes positivos generales y su fundamentación.” En Doxa, № 3 (1986).

Ética, ob. cit, p. 287. 
ética kantiana. Hay que precisar algo: para Kant no basta convertirse en medio, tiene que ser un mero medio, es decir, la ética kantiana prohíbe tratar a alguien sólo como medio, no como un medio y a la vez un fin. Pues bien, el sujeto que desea suicidarse no desea vivir de modo que forzarlo a vivir contra su voluntad no es tratarlo como un fin, sino sólo como un medio.

\section{El argumento religioso.}

De todos los argumentos presentados en contra de disponer de la vida, el único que puede hacer algún sentido es el argumento religioso. Por tanto, tienen razón los autores ${ }^{72}$ que señalan que quien se opone al suicidio normalmente ${ }^{73}$ lo hace por razones religiosas. Un autor lo pone del siguiente modo:

"[E]s evidente que los partidarios de este enfoque le atribuyen al derecho a la vida fundamentos que van más allá de la Constitución, pues normalmente vinculan esta idea con alguna religión o deidad que nos habría otorgado la vida como don sagrado." 74

La Corte de Apelaciones, en su fallo transcrito más atrás, no disfraza el fundamento de su decisión en este punto: cita derechamente la civilización judeo-cristiana y la "Teología" para prohibir disponer de la vida.

72 Varios autores sostienen que quienes se oponen a disponer de la vida normalmente lo hacen por razones religiosas. Por ejemplo, Calsamiglia, Albert, "Sobre la Eutanasia" en Doxa, No 14, 1993, p. 339; Thomson, Judith, en "Physician-Assisted Suicide: Two Moral Arguments." En Ethics 109 (April 1999), University of Chicago, p. 506; Kuhse, Helga. "La Eutanasia" en Compendio de Ética. Editado por Peter Singer. Editorial Alianza, Madrid, 1991. p. 405; Nino, Carlos. Etica, ob. cit, p. 288; Gómez, Gastón. Derechos Fundamentales y Recurso de Protección., ob. cit. p. 252. En el caso de Dworkin, es importante distinguir dos tesis: que la vida sea disponible o que la vida tenga un valor intrínseco. Respecto de eso último, Dworkin ha señalado, con razón, que tanto religiosos como ateos puede suscribir la tesis de que la vida tiene un valor intrínseco: "También los ateos pueden sentir instintivamente que el suicidio y la eutanasia son problemáticos porque la vida humana tiene un valor intrínseco.” P. 255. Pero eso no implica indisponibilidad, sino que es problemático. El mismo Dworkin agrega dos líneas más abajo: “...la convicción de que la vida humana es sagrada puede suministrar una base para proveer un argumento crucial en favor, y no en contra, de la eutanasia.” p. 255. Ahora, respecto de la indisponibilidad, esta idea-dice Dworkin- está ligada a posiciones religiosas conservadoras. Ver p. 280. Dworkin, Ronald, El dominio de la Vida, ob. cit.

73 En la cita de Aristóteles, no existe ningún argumento. Lo que señala Aristóteles es que quien se daña a sí mismo o se mata actúa injustamente, pero no sabemos por qué. Ver Ética Nicomáquea, Libro V, Capítulo 11, 1138, $5-10$.

74 Gómez, ibid. 
Este argumento puede tener algún sentido porque la única razón por la cual un individuo no podría disponer de algo es porque no le pertenece, de modo que si pensamos en la vida y sostenemos que las personas no son dueñas de su vida, entonces al único a quien podría pertenecerles es a Dios. Dice un autor: “...la apelación a la santidad de la vida utiliza la imagen de la propiedad: la vida de una persona no le pertenece sino que constituye una propiedad de Dios. ${ }^{75}$ Este argumento religioso, o más bien teológico, tiene debilidades insalvables.

En primer lugar, no es un argumento sino una petición de principio: la vida pertenece a Dios. Esa es una petición, no una razón, y no parece haber ninguna razón para creer en esa petición, salvo -claro- la fe de algunos.

En segundo lugar, debemos recordar que autores clásicos que lo mencionaron no lo hicieron con carácter absoluto, es decir, la vida no es absolutamente indisponible. En efecto, en El Fedón, a continuación del pasaje donde que Platón menciona la indisponibilidad de la vida por pertenecer a los dioses, dice lo siguiente:

“-Y tú, en tu caso - prosiguió- si alguno de los seres que son de tu propiedad se suicidara, sin indicarle tú que quieres que muera, ¿no te irritarías con él?; y si pudieras aplicarle algún castigo, ¿no se lo aplicarías?

-Sin duda alguna -respondió Cebes.

-Pues bien, quizá desde este punto de vista no sea ilógica la obligación de no darse muerte a sí mismo, hasta que la divinidad envíe un motivo imperioso, como el que ahora se me ha presentado." 76

Locke, por su parte -quien también utilizó el mismo argumento- también reconoce que la vida sí es disponible. En la misma sección en que alude a este principio de la indisponibilidad -y que se ha citado más arriba- Locke agrega: “...y a menos que se trate de hacer justicia con quien haya cometido una ofensa, no podrá quitar la vida, ..."77

En tercer lugar, Hume también ha formulado críticas a este postulado teológico, particularmente en relación con contrariar la voluntad divina, Dice Hume: "Si el suicidio es de

\footnotetext{
75 Dworkin, ob. cit, p. 280

76 Platón, Fedón, 62 c).

$77 \quad$ Locke, ob. cit, p. 38.
} 
naturaleza criminal, ha de constituir una trasgresión de nuestros deberes para con Dios, para con nuestro prójimo, o para con nosotros mismos." 78 Dicho esto, Hume intenta demostrar que el suicidio no puede constituir una trasgresión de deberes para con Dios. Señala:

"Si el disponer de la vida humana fuera algo reservado exclusivamente al Todopoderoso, y fuese un infringimiento del derecho divino el que los hombres dispusieran de sus propias vidas, tan criminal sería el que un hombre actuara para conservar su vida, como el que decidiese destruirla. Si yo rechazo una piedra que va a caer sobre mi cabeza, estoy alterando el curso de la naturaleza, y estoy invadiendo una región que sólo pertenece al Todopoderoso, al prolongar mi vida más allá del período que, según las leyes de la materia y el movimiento, El le había asignado." 79

Probablemente nadie se comportaría de ese modo ni suscribiría esa postura.

En cuarto lugar, sabemos que en algunas culturas el suicidio no sólo no está moralmente prohibido sino que es moralmente exigido en ciertas situaciones sobre la base de una cierta concepción del honor personal. Incluso en la cultura occidental, existe una forma de suicidio -la muerte heroica- que es admitida e incluso admirada. Si se admite disponer de la vida en ese caso, debe permitirse también en otros, como señala Hume ${ }^{80}$. De lo contrario, se incurre en una contradicción. En efecto, el héroe no es más dueño de su vida que el suicida depresivo. Ugarte menciona el caso del héroe e intenta salvar la contradicción acudiendo a la doctrina del doble efecto. Esto último es infructuoso dada la insustentabilidad de dicha doctrina ${ }^{81}$. Lo que

78 Hume, ob. cit, p. 123.

79 Ibid, p. 127. Debe apuntarse que Hume señala que el contexto es suponer que Dios controla todo lo que sucede. Ver pp. 123-127.

80 [S]i mi vida no me perteneciera a mí, sería ciertamente criminal ponerla en peligro o disponer de ella; no podría un hombre merecer el apelativo de héroe por arriesgarse a los mayores peligros en busca de gloria o en defensa de la amistad, ni otro hombre el calificativo de vil o miserable porque pone fin a su vida por iguales o parecidos motivos." Hume, ob. cit, p. 129.

$81 \quad$ La doctrina del doble (DDE) es utilizada por la tradición escolástica y autores que siguen el magisterio de la Iglesia Católica con la finalidad de intentar salvar una contradicción: justificar dejar morir a alguien y condenar matar a alguien. Por ejemplo, matar al feto se considera injusto, pero se considera justo matar a la mujer por la vía de dejarla morir cuando el embarazo no puede llegar a buen final; que alguien se quite la vida es injusto pero es justo que alguien pierda la vida intentando rescatar a otro sabiendo que con ello morirá.

Esta doctrina supone que una conducta puede tener dos efectos, uno querido y otro no querido pero inevitable. Con ello, esta doctrina requiere además, distinguir moralmente entre acciones y omisiones.

Existe bastante literatura que analiza y descarta la DDE así como el intento de distinguir moralmente entre acciones y omisiones. Ver Foot, Philipa. "La doctrina del Doble Efecto" en Las Virtudes y los Vicios. Traducción de Claudia Martínez. Universidad Nacional Autónoma. Instituto de Investigaciones Filosóficas, México, 1994; 
parece ocurrir es que Ugarte valora de modo distinto lo que Durkheim llama suicidio egoísta del suicidio altruista ${ }^{82}$. Pues bien, una valoración distinta de ambas situaciones no tiene sentido a luz del argumento religioso, que se funda no el valor de la conducta sino en la titularidad del bien.

Además del suicidio altruista, la pena de muerte genera un nuevo problema de coherencia para quienes sustentan este principio. En efecto, si la vida pertenece a Dios, ¿cómo es posible disponer de ella mediante la pena de muerte? Como afirma acertadamente Nino, quien desee justificar la pena de muerte no puede oponerse al suicidio con el argumento de la indisponibilidad de la vida ${ }^{83}$, pues se caería en una incoherencia. En este punto, Ugarte otra vez queda en problemas, debido a que él justifica la pena de muerte ${ }^{84}$ apoyado en el magisterio de la Iglesia Católica.

Otra incoherencia en la postura mayoritaria es evidente. La mayoría de la doctrina definió el derecho a la vida como el derecho a vivir bien, o vivir con dignidad. Es decir, no consideran relevante la vida por sí sola, como una mera facticidad, sino lo que se hace con ella o cómo se vive. Pues bien, esa postura debiera llevar -como llevó a Sócrates- a la tesis contraria, de la disponibilidad de la vida, cuando no se puede vivir bien o con dignidad. La incoherencia se produce porque la tesis de la indisponibilidad valora la vida como mera realidad fenoménica, independiente de lo que su titular piense o desee hacer con ella.

En quinto lugar, y además de todas las consideraciones previas, no debe perderse de vista que estamos ante un tema constitucional, no solamente moral. Y en temas constitucionales no son aceptables los argumentos o principios religiosos o teológicos, dado el carácter laico, tolerante e inclusivo del Estado democrático contemporáneo.

Garzón, Ernesto “Deberes Positivos” en Doxa n 3, 1986; Singer, Peter, Ética Práctica, editorial Ariel, Barcelona, 1984, pp. 187 y ss; Thomson, Judith. "Physician-Assisted Suicide", ob. cit, pp. 509ss, especialmente la sección $\mathrm{V}$.

82 Durkheim. E. El suicidio. Traducción de Mariano Ruiz-Funes. Editorial Reus. Madrid, 1928.

83 "La revisión de estos argumentos nos permite concluir que si se acepta una justificación consensual de la pena (o, en realidad, cualquier concepción no totalitaria del poder estatal de castigar), difícilmente puede defenderse coherentemente tanto la proscripción del duelo, la ayuda al suicidio, etc, como la legitimidad de la pena de muerte. Si se sostiene que el consentimiento del afectado torna legítima una pena de muerte que es necesaria y eficaz para proteger la sociedad contra males mayores que los que ella implica, entonces debe restringirse severamente la interferencia estatal con actos contra la vida en los que la voluntad del individuo afectado está involucrada." Nino, Ética, ob. cit, p. 288. En la p. siguiente agrega que si se adhiere a la idea de que la vida es indisponible, entonces la pena de muerte necesariamente es ilegítima, p. 289.

84 Ver Ugarte, EI Derecho a la Vida, ob. cit, primera parte, cap. III. 
En sexto lugar, es posible presentar argumentos independientes en favor de la disponibilidad de la vida:

6.1. En primer lugar, para sostener que la vida no puede ser objeto de disposición de parte del propio sujeto y concluir que eso infringe el artículo $19 \mathrm{n}^{\mathrm{o}} 1$, es necesario suponer que el objeto del derecho a la vida es la vida misma. Si uno supone que el objeto del derecho es la vida, entonces disponer de ella vulnera el derecho, independientemente de quien lo haga. Pues bien, ya hemos señalado más atrás que el objeto de un derecho a algo -como lo llama Alexy- no puede ser una cosa o entidad ni la conducta del titular del derecho, y se han dado las razones pertinentes. Si aceptamos que el objeto del derecho a la vida, como el de cualquier derecho a algo es la conducta de un tercero, advertiremos que la conducta del titular no resulta regulada por ese derecho. Por tanto, ninguna conducta del titular puede infringir ese derecho. Esto significa que si el titular se quita la vida, no infringe su derecho a la vida, porque su conducta no guarda relación conceptual ni dogmática con el derecho ${ }^{85}$. Si el derecho a la vida significa el derecho a que otro no nos mate arbitrariamente, el acto de disposición de la vida de parte del titular de ella no posee relevancia jurídica. Así pues, un sujeto puede disponer de su vida sin que ello infrinja el derecho constitucional. Esto permite advertir que ni el suicidio ni la huelga de hambre hasta la muerte -que es una forma de suicidarse- infringen el derecho a la vida.

De hecho, la sala de la Corte de Apelaciones que primero conoció el caso de huelga de hambre citado más atrás, lo declaró inadmisible por la ausencia de intervención de un tercero:

"Que el artículo 20 de la Constitución Política del Estado se refiere a los actos u omisiones arbitrarias o ilegales que sufre una persona en menoscabo de sus garantías constitucionales;

Que lo anterior implica que dichos actos en omisiones dimanan de terceras personas, lo que no ocurre en la especie..." (30 de julio de 1984).

La corte tiene claridad de que la vulneración del derecho requiere la intervención de terceras personas. Sin embargo, su resolución fue apelada y la Corte Suprema declaró admisible el asunto, remitiéndolo a otra sala de la Corte de Apelaciones ${ }^{86}$.

\footnotetext{
85 Aquí estamos hablando de derechos. Distinta es la situación de los deberes. Un sujeto puede tener deberes morales para consigo mismo. Por ejemplo, deberes tendientes a algún ideal de perfección o excelencia individual.

86 La Corte Suprema no sólo lo declara admisible, sino que señala de modo explícito que debe acogerse, lo que
} 
6.2. En segundo lugar, existe un argumento a fortiori para permitir la disposición de la vida. Sabemos que está justificado disponer de la vida de otro contra su voluntad en ciertos casos. Por ejemplo, en legítima defensa. Otro caso, según la Constitución chilena, es la pena de muerte. Pues bien, si está justificado matar a otro contra sus deseos, no tiene lógica que esté prohibido que el mismo individuo se mate voluntariamente. Desde el punto de vista de la disponibilidad, que esté permitida para terceros pero no para el titular carece de sentido; o se permite en ambos casos o en ninguno, y como todas las personas permitirán la disposición de la vida de un tercero al menos en un caso (legítima defensa), entonces no queda otra alternativa que permitir que el titular pueda disponer de su vida.

6.3. Un tercer argumento en favor de la disponibilidad de la vida es la autonomía del individuo (adulto competente). El argumento es el siguiente: lo que da valor a la vida es la autonomía. Dice Calsamiglia: "[S]in autonomía, los actos humanos carecen de valor." ${ }^{87}$ En efecto, consideramos un valor fundamental el que las personas sean libres para determinarse a sí mismas, con exclusión del daño a terceros. Ningún derecho fundamental puede tener algún sentido si no partimos del principio básico de la autodeterminación: la libertad de expresión, el derecho de propiedad, la libertad de locomoción, la libertad de trabajo, etc, no tienen relevancia si no asumimos que el sujeto es libre para decidir su propia vida. La sola idea de responsabilidad supone capacidad de autodeterminación.

Calsamiglia, aludiendo al argumento de que la eutanasia constituye un daño por la pérdida de la vida, agrega: "[U]n estado que pretenda ser justo desde el punto de vista liberal no puede interferir en esa decisión porque debe dejar la elección del daño al destinatario." 88 Dworkin lo enfrenta del siguiente modo:

[D]e esta forma, la invocación de la santidad de la vida hace surgir aquí la misma cuestión crucial, de carácter político y constitucional, que surge acerca del aborto. Una vez más la pregunta crítica es si una sociedad decente elegirá la coerción o la responsabilidad, si procurará imponer a todos un juicio colectivo sobre asuntos de índole más profundamente espiritual, o si permitirá y pedirá a sus ciudadanos que realicen por sí mismos los juicios trascendentales, definitorios de su personalidad, sobre su propias vidas." $" 89$

probablemente influyó en la sala de la Corte de Apelaciones que terminó viendo el asunto.

87 Calsamiglia, ob. cit, p. 339.

$88 \quad$ Ibid, p. 345. También Kuhse, ob. cit, p. 406.

89 Dworkin, ob. cit, p. 282. 
Debemos agregar que la Constitución Política confiere a la autonomía de la persona una importancia central en el artículo 1 y es la base de los derechos fundamentales recogidos en los capítulos II y III. Por tanto, una tesis como la indisponibilidad de la vida no es compatible con el principio de autonomía reconocido por la Constitución. Por ejemplo, obligar a las personas a vivir -imaginemos aquellas que están bajo enorme sufrimiento físico-vulnera ese principio constitucional. No cabe duda que la mayoría de la doctrina nacional -que suscribe la tesis de la indisponibilidad- adhiere al valor central de la autonomía, es decir, creen que es fundamental que el individuo controle su propia vida. Lo que no tiene sentido es por qué excluyen de ese control el acto final de sus vidas.

6.4. En cuarto argumento contra la indisponibilidad, relacionado con el anterior, está basado en el principio de que nadie debe ser cruel con los demás. Calsamiglia, hablando de la eutanasia, lo dice del siguiente modo: "[E]l estado no puede imponer el sufrimiento a las personas que piden morir." 90 Dice este autor:

"[L]os defensores de la eutanasia sostienen que quienes defienden el paradigma estricto (vgr. la vida es sagrada e indisponible) son crueles porque la vida con gran sufrimiento y sin esperanza de supervivencia carece de sentido." ${ }^{\prime 1}$

Pensemos en una persona adulta y competente que seriamente ha adoptado la decisión de suicidarse. Es tal situación, la muerte es preferible a la vida. Y no es una preferencia trivial, sino fundamental. Para ese sujeto, la vida es a tal punto insoportable que prefiere morir. La tesis de la indisponibilidad de la vida se traduce en forzar o condenar a esa persona a seguir viviendo, no obstante que le sea intolerable. Imaginemos una persona enferma terminal que inevitablemente va a morir pronto y se encuentra bajo intenso sufrimiento; esa persona es capaz de suicidarse y desea hacerlo para morir bien. Forzar a esa persona a vivir en tan miserables condiciones y morir del peor modo no puede sino constituir un trato cruel, que no es compatible con el derecho a la integridad psíquica y trasgrede el derecho internacional que el artículo 5 de la Constitución manda respetar y promover.

6.5. Un quinto argumento, también emparentado con los dos principios anteriores, apunta a la dignidad. Forzar la mantención de la vida en ciertas condiciones puede constituir un atentado a la dignidad ${ }^{92}$, que también es un criterio fundamental recogido por el artículo $1^{\circ}$ de

Calsamiglia, ob. cit, p. 345 .

Ibid, p. 339. Kuhse, ob. cit, p. 406.

Ver Calsamiglia, op. cit, p. 345, y Feinberg, Joel, Harm to Others, Oxford University Press, USA, 1987, p. 354. 
la Constitución. Ningún sistema de reglas - dice Garzón- puede fijarse transgrediendo la dignidad humana ${ }^{93}$. Impedir que un sujeto competente pueda disponer de su vida implica forzarlo a conseguir para sí mismo otros fines que los que él se ha fijado, anular su capacidad de discernimiento y de agente moral y considerarlo como si fuera un incompetente básico, que requiere paternalismo. Cuando A dice a $\mathrm{B}$ que no puede disponer de su vida, lo que está haciendo y esperando es que B valore la vida tal como A lo hace; si A le ve sentido a su vida, entonces B también debe vérselo. Se viene a la mente aquella escena de la película Mar Adentro, cuando el sacerote parapléjico visita a José Sanpedro y tratar de convencerlo que la vida sí tiene sentido, incluso para un tetrapléjico. Esto significa que A no trata a B como una persona capaz de tener su propia visión de sí mismo y de su propia vida y de actuar en conformidad a esa visión. Esta postura niega al individuo su carácter de agente moral, su autonomía y, finalmente, su dignidad. "[H]acer que alguien muera en una forma que otros aprueban, pero que él cree que es una contradicción horrorosa con su propia vida, constituye una devastadora y odiosa forma de tiranía." ${ }^{94}$

La tesis de la indisponibilidad implica esto y por ello -agrega Garzón- es incompatible con un sistema de derechos fundamentales.

Con estos comentarios, se cierra esta sección destinada a discutir la disponibilidad de la vida.

\section{El derecho a la vida frente a otros derechos.}

Hemosrevisadocuatroconcepciones sobreelderechoalavidayheproporcionadoargumentos paradescartarlas. Laversiónqueserecogeacásostienequeelderechoalavidaconsistesimplemente en el derecho a que no nos maten arbitrariamente. Este modo de entender el derecho a la vida evita confundirlo, como lo ocurre a la mayoría de la doctrina nacional, con el derecho a la salud ${ }^{95}$ o con el derecho a la integridad física ${ }^{96}$. Veremos algunos argumentos para evitar esta confusión.

93 Garzón, Ernesto. “¿Cuál es la relevancia moral del concepto de dignidad humana?”. Inédito, p. 39.

94 Dworkin, ob. cit, p. 284.

95 Evans sostuvo que "[E]l enfermo tiene, también, derecho a que se preserve su vida y, por tanto, a las técnicas médicas necesarias...”, ob. cit, p. 113.

96 Como vimos en una nota anterior, Verdugo y Pfeffer se apoyan en la Comisión de Estudio y citan: “...se infiere que el reconocimiento al derecho a la vida aparece referido preferentemente al soporte biológico y psíquico del hombre. Es así como el derecho a la integridad física y psíquica de la persona fue aprobado por vía consecuencial: "Si una persona es mutilada o torturada, ya sea física o psicológicamente, se está atentando en contra de su vida." (Sesión No 87, pág. 4).” ob. cit, p. 198. 


\subsection{Derecho a la salud.}

Hablar del derecho a la salud resulta especialmente difícil atendido que prácticamente no existen elucubraciones dogmáticas referidas a él en la literatura jurídica nacional. De modo provisorio podemos decir que el derecho a la salud no significa el derecho a estar sano o a recuperar la salud porque eso puede ser imposible. Por ejemplo, una enfermedad incurable es, pues, incurable. El sólo hecho de padecerla no implica que se vulneró o vulnera su derecho a la salud. Más bien podemos entender que el derecho a la salud consiste en el derecho a recibir prestaciones médico-sanitarias, aunque no podamos precisar por ahora cuáles, bajo qué condiciones y, sobre todo, quien tendría la obligación de proporcionarlas.

Con todo, esta sumaria aproximación permite distinguir el derecho a la salud del derecho a la vida. Se viola el derecho a la vida de $\mathrm{X}$ cuando se lo mata arbitrariamente. En cambio, se viola el derecho a la salud de X cuando no se efectúan a su respecto las prestaciones médicosanitarias que sean pertinentes (suponiendo que $\mathrm{X}$ tenga derecho a exigirlas). $\mathrm{G}$ (el objeto del derecho) es distinto en ambos casos. Llamaremos Gdvida al objeto del derecho a la vida y llamaremos Gdpsalud al objeto del derecho a la salud (a la protección de la salud, como dice el artículo $19 \mathrm{n}^{\circ}$ 9). Gdvida consiste en la obligación de no matar arbitrariamente y Gdpsalud consiste en la obligación de efectuar ciertas prestaciones médico-sanitarias. Pues bien, es posible infringir Gdvida sin vulnerar Gpsalud cuando se mata alguien sano, y se viola Gdpsalud sin trasgredir Gdvida cuando no se proporcionan prestaciones de salud a alguien sin que eso le ocasione la muerte.

Obviamente se pueden conculcar ambos derechos simultáneamente, por ejemplo, cuando el agresor busca matar a alguien por la vía de no proporcionarle las prestaciones médicosanitarias que requiere para salvarse. Sin embargo, el que la infracción de $\mathrm{G}$ en ambos casos pueda tener en común la muerte del titular no debe llevarnos a confundir ambos derechos.

\subsection{Derecho a la integridad física y psíquica.}

Pudimos advertir más arriba que, además de confundir el derecho a la vida con el derecho a la salud, algunos autores lo confunden con el derecho a la integridad física y psíquica. Por ejemplo, unos autores señalan: "Si una persona es mutilada o torturada, ya sea física o psicológicamente, se está atentando en contra de su vida." $" 97$

$97 \quad$ Verdugo, Mario, et. al, ob. cit, p. 198. 
Esta frase o es trivial o es errada. Si cuando usan la palabra vida se refieren a la calidad de vida de la persona, es evidente que cuando se tortura o mutila a alguien, se atenta contra su calidad de vida, pero eso es trivial. Pero si se refieren al derecho a la vida-como creo que es el caso- esa frase es errada pues es físicamente posible torturar o mutilar a alguien sin matarlo. G también es distinto en estos casos. El objeto del derecho a la integridad física y psíquica es la obligación de no conculcar la integridad física o psíquica de alguien. Por ejemplo, se vulnera la integridad física cuando se mutila a alguien, y se vulnera su integridad psíquica cuando se la somete a tormentos, a amenazas, etc. Es posible mutilar a alguien sin matarlo, con lo cual se trasgrede el derecha a la integridad física pero no el derecho a la vida, y si se atormenta a alguien, se infringe su derecho a la integridad psíquica sin, con ello, violar su derecho a la vida.

Por cierto, al igual como ocurre con el derecho a la salud, es posible que al infringir el derecho a la integridad física o psíquica se vulnere también el derecho a la vida, si se mutila a alguien de modo tan grave que lo mata, o cuando torturan a alguien hasta morir, pero eso no debe llevarnos a confundir estos derechos.

\section{Triple esquema de obligaciones del derecho a la vida.}

Hasta aquí hemos establecido que el derecho a la vida implica la obligación negativa de no matar arbitrariamente. Sin embargo, esa no es la única obligación que emana del derecho. Para explicar este asunto partiremos de una consideración más general, que se aplica a cualquier derecho.

En cualquier derecho es posible distinguir tres niveles de obligaciones:

a. obligación primaria de respetar: significa que el Estado y sus agentes deben abstenerse de lesionar un derecho. Esta es una obligación de carácter negativo.

b. obligación secundaria de proteger: significa que el Estado y sus agentes deben adoptar medidas concretas para impedir que terceros priven al titular de su derecho. Este concepto comprende muchas obligaciones de carácter positivo, necesarias para impedir que terceros trasgredan el derecho del titular.

c. obligación terciaria de satisfacer-cumplir: significa que el Estado debe realizar acciones concretas para lograr el goce efectivo y pleno del derecho. Esta categoría también comprende obligaciones de carácter positivo, y probablemente son muchas. 
Esta teoría de que los derechos hay que entenderlos como un triple esquema de obligaciones ha sido desarrollada por Shue ${ }^{98}$, Eide ${ }^{99}$, Alexy ${ }^{100}$, y el Comité DESC ${ }^{101}$ de la ONU. Evidentemente el principal problema de este triple esquema consiste en la determinación exacta de las obligaciones que emanan de los derechos, particularmente las de nivel secundario y terciario. De eso se ha estado ocupando la doctrina internacional por años y el comité DESC, pero no es el caso entrar en ello ahora.

Aplicando este triple esquema de obligaciones al derecho a la vida, tenemos lo siguiente:

a) A nivel primario, el Estado y sus agentes deben abstenerse de matar al individuo injustificadamente. ${ }^{102}$ Esta obligación negativa se cumple simplemente con una omisión. Esta parece ser una obligación de resultado.

Shue, Henry. Basic Rights. Subsistence, Affluence and U.S. Foreign Policy. Princeton University Press. Princeton, New Jersey. 1980, p. 52.

99 Eide , Asbjorn. "Realization of Social and Economic Rights and the Minimum Threshold Approach." HRLJ vol 10, N. 1-2 (1989). p. 37; Eide, Absjorn. "National Sovereignty and International Efforts to Realize Human Rights." In Human Rights in Perspective: A Global Assessment. (Eds.) Absjorn Eide \& Berut Hagtvet. Blackwell Publishers. Oxford, 1992, p. 5.

100 En menor medida. Ver Alexy, Robert. Teoría de los Derechos Fundamentales. ob. cit, p. 188.

101 El Comité DESC recoge este triple esquema respecto de los DESC. Pero ese esquema es aplicable a derechos civiles, según vemos en el esquema original de Shue, en la reformulación que realiza Eide y en la teoría de Alexy. General Comment $\mathrm{N}^{\circ}$ 12. At. 15. "The right to adequate food, like any other human right, imposes three types or levels of obligations on States parties: the obligations to respect, to protect and to fulfil. In turn, the obligation to fulfil incorporates both an obligation to facilitate and an obligation to provide. The obligation to respect existing access to adequate food requires States parties not to take any measures that result in preventing such access. The obligation to protect requires measures by the State to ensure that enterprises or individuals do not deprive individuals of their access to adequate food. The obligation to fulfil (facilitate) means the State must proactively engage in activities intended to strengthen people's access to and utilization of resources and means to ensure their livelihood, including food security (sic)."

102 En Chile, el autor que ha presentado una visión analítica del derecho a la vida es Gastón Gómez. Sobre este punto referido a las obligaciones que emanan del derecho a la vida, él señala expresamente que el enunciado "derecho a la vida" exige acciones positivas y negativas de parte del Estado: "[S]i pudiéramos sintetizarlo, deberíamos decir que el derecho a la vida cubre o ampara las siguientes posiciones: a) Todas las personas (...) son puestas por el enunciado del art. $19 \mathrm{~N}^{\mathrm{o}} 1$ en la posición de exigir que el Estado no los prive ilegítimamente de su vida, (ni de su integridad física y psíquica). Gómez, ob. cit, p. 249.

Evans también alude correctamente a una obligación primaria de respetar, en la letra b) que se cita a continuación (no en la a)): "El derecho a la vida supone el derecho a la legítima defensa física, recogido por la ley penal, e impone, además, dos obligaciones: a) La de respetar la propia vida, por lo cual la ley penal sanciona la tentativa de suicidio, y b) La de respetar la vida de los otros seres humanos." p. 114. (En la letra a) comete el error de regular la conducta del titular).

Nogueira también identifica obligaciones positivas y negativas derivadas del derecho a la vida, para el Estado y sus agentes. Ob. cit, pp. 52-53. 
b) A nivel secundario, el Estado y sus organismos deben adoptar medidas concretas para prevenir que terceros maten al individuo arbitrariamente ${ }^{103}$. Esta obligación es de carácter positivo y bastante difusa. Parece inevitable concebirla como una obligación de medios y no de resultado.

Muchas medidas se pueden adoptar para intentar razonablemente impedir, aunque no asegurar, que terceros maten al individuo de modo arbitrario. Por ejemplo, se adoptan pasos progresivos en el cumplimiento de esta obligación cuando el Estado castiga severamente atentar contra la vida, criminalizando esa conducta y disponiendo un sistema de justicia criminal; también cuando el Estado dispone de una fuerza policial capaz de efectuar labores preventivas de protección de manera razonable. Dado que esta obligación es positiva y de medios siempre es posible preguntarse qué más debe hacer el Estado para proteger de un modo razonable a las personas en su derecho a la vida. Un extremo sería poner escolta permanente a todas las personas, o guarnecer a todos en sus domicilios o facilitar armas u otros dispositivos de defensa a todas las personas adultas. El problema radica en hallar algún punto intermedio, que probablemente pasa por determinar las causas que llevan a una persona a matar a otra, asunto obviamente dificultoso.

c) A nivel terciario, el Estado y sus organismos deben adoptar medidas positivas para satisfacer-cumplir el derecho a la vida, es decir, el pleno goce de este derecho.

Normalmente, respecto de los DESC y también tratándose de algunos derechos civiles (como el derecho a un debido proceso, el derecho a la privacidad, etc), las obligaciones positivas asociadas a ellos en este nivel son considerablemente más difusas que las obligaciones de primer nivel pues tienen como objetivo que el derecho se entienda satisfecho o cumplido. Tratándose del derecho a la vida, es posible que no existan obligaciones terciarias distintas de las primarias y secundarias. Esto no necesariamente es exclusivo de este derecho; puede ocurrir también con el derecho a la libertad personal, la libertad de expresión, etc.

103 Ver también Gómez: "b) Las personas son puestas en la posición de exigir que el Estado evite que terceros nos priven ilegítimamente de la vida (y de la integridad física y psíquica).” Gómez, ob. cit, p. 249.

Evans formula un comentario que corresponde precisamente a una obligación secundaria de proteger: "Todo ser humano tiene el derecho esencial de conservar su vida y de exigir que el ordenamiento jurídico se la proteja contra atentados de la autoridad o de particulares." p. 113. Luego, Evans cita a Manuel Guzmán: "Entendemos por derecho a la vida la facultad jurídica, o poder, de exigir la conservación y la protección de la vida humana, o sea, de ese estado de actividad sustancial propio del hombre. Considerado como un derecho subjetivo, importa una facultad de querer y de obrar, de carácter imperativo, que persigue exigir de otros el respeto a ese estado, y que debe ir seguido de la correspondiente obligación por parte de los demás...” Evans, ibid. Aquí se puede advertir como existe una alusión a obligaciones primarias y secundarias. 
Podemos partir por señalar qué no corresponde a este nivel. Por lo pronto, puede ser útil recordar la distinción entre vida y derecho a la vida y entender que este nivel terciario apunta al pleno goce del derecho a la vida y no a la plena satisfacción de la vida. En este sentido, el Estado no tiene obligaciones derivadas del derecho a la vida de hacer cosas para que la vida de las personas sea más plena o significativa para ellas. Ideas como llevar una vida digna o un cierto estándar de vida deben considerarse ajenas a este derecho. Quizá el Estado pueda tener alguna obligación de medios conducente a esos objetivos y que se derive de otros principios, como la dignidad como criterio constitucional, pero no del derecho a la vida.

Es posible que el nivel terciario se entienda cumplido cuando lo han sido el primario y secundario, cuestión que ciertamente no ocurre con los $\mathrm{DESC}^{104} \mathrm{y}$ varios otros derechos civiles. En efecto, si el derecho consiste en que no me maten arbitrariamente, este derecho se entenderá satisfecho o cumplido cuando la persona muere pero no arbitrariamente y pueda, entonces, predicarse que el Estado desempeñó un razonable papel respecto de sus obligaciones primarias y secundarias. En todo caso, este es un tema abierto.

\section{Arbitrariedad.}

He sostenido que el derecho a la vida debemos entenderlo como el derecho a que no nos maten arbitrariamente. Esto exige analizar los casos en que se puede estimar que se mata a alguien de modo no arbitrario, es decir, justificado. Como se dijo en una sección anterior, en este trabajo - por espacio- no podré considerar estos casos, que son varios y requieren de análisis y discusión detenida, como los casos de defensa (legítima defensa y estado de necesidad defensivo), o cuando se cuenta con el consentimiento del afectado (como el suicidio asistido, la eutanasia voluntaria), o la pena de muerte. Por tanto, estos importantes asuntos quedarán para otra oportunidad.

\section{Síntesis.}

Por tanto, de modo preliminar, podemos sostener que el derecho a la vida significa:

a) La obligación primaria negativa de no matar arbitrariamente a otro.

b) Obligaciones positivas secundarias necesarias para prevenir que se mate arbitrariamente

104 Esto no significa que los DESC tengan 3 niveles y que los derechos civiles y políticos sólo dos. Hay otros derechos civiles en que se aprecian claramente los tres niveles de obligación. Por ejemplo, el derecho al debido proceso, la igualdad ante la ley, etc. 
a otro. Estas obligaciones son muchas y deben determinarse. Por ejemplo, disponer de un Código Penal que sancione el homicidio, disponer de Fiscalías que persigan y Tribunales que sancionen a los infractores, disponer de cárceles, disponer de policía que efectúe labores preventivas, y una serie de otras acciones que tengan que ver con las causas o condiciones que llevan a alguien a matar a otro.

c) Eventualmente obligaciones positivas destinadas a satisfacer-cumplir el derecho, que habría que determinar.

En cuanto a que la muerte que no sea arbitraria, quedará pendiente por ahora un análisis de aquellos casos en que estaría justificado matar a otro, como podría ser en caso de defensa (legítima defensa y estado de necesidad defensivo), o cuando se cuenta con el consentimiento del afectado (como eutanasia voluntaria), o la pena de muerte. 